\title{
High Performance Computing Prediction of Potential Natural Product Inhibitors of SARS-CoV-2 Key Targets
}

\author{
Kendall Byler\%, Joseph Landman\#, Jerome Baudry\%* \\ \%: The University of Alabama in Huntsville, Department of Biological Sciences, Huntsville, AL, 35899 \\ \#: Hewlett Packard Enterprise, HPC MCS Al, Canton, MI, 48188 \\ *Corresponding author: jerome.baudry@uah.edu
}

\begin{abstract}
An ensemble-docking of 50,000 natural products on a supercomputer has been performed against the papain-like protease, the main protease and the spike protein of the SARS-CoV-2 virus. The top compounds predicted to bind specifically to these protein targets are analyzed to identify common pharmacophore features. The functional groups more likely to lead to target engagement of these viral proteins are described and feature hydrophobic/resonant cores surrounded by hydrogen bonding capacities at specific locations. This work identifies natural products for immediate testing and suggests structural elements for anti COVID-19 drug development and screening.
\end{abstract}

\section{Introduction}

The fight against COVID-19 has led to an unprecedentedly large-scale effort to discover pharmaceuticals that are active against the virus or that cure or mitigate the ill health effects of the SARSCoV-2 infection. This endeavor has been so far mostly following a strategy of repurposing existing drugs, in the hope that existing pharmaceuticals will prove efficient against the disease. This repurposing approach is powerful and can help accelerate the availability of efficient pharmaceuticals. These existing pharmaceuticals have known safety profiles and are therefore largely "de-risked". This approach not only speeds up the drug discovery process, but also limits its cost, by bypassing a large part of the development of new chemical entities (NCEs). In non-crisis, "normal" times, however, repurposing/repositioning efforts can still be lengthy processes, and typically take 1-6 years of preclinical and clinical research to get FDA approval for drugs already in use. And getting the licensing for the novel use of repurposed drugs can tack on as many as two years on the front end. It is expected and hoped that the approval of new drugs against COVID19 will be expedited by the regulatory agencies without, naturally, sacrificing the quality and safety of the drug approval process. Repurposing is, however, not the only approach to drug discovery against COVID-19. New chemical entities are likely to be needed, even if the repurposing effort is successful. Repurposed drugs may be active against the virus itself but may not be as efficient as against the more traditional targets they were developed against. In fact, relatively few drugs have been successfully used in repurposed indications ${ }^{1}$. On the other hand, NCEs, even if they represent the vast majority of current drugs, are notoriously time-consuming and expensive to develop. The process also suffers from a very low success rate (contributing to both development time and cost) as most NCEs are found to fail in later-stage pre-clinical and clinical stages of drug development because of unfavorable chemical profiles and their incompatibility with the necessary biological balance between efficacy and safety of biochemicals.

This present work aims to accelerate the discovery of novel pharmaceutical approaches to the COVID-19 crisis by minimizing the issues of repurposing existing pharmaceuticals (very few efficient drugs originate from repurposing) and of developing NCEs (very long development times and very high cost). We aim to identify molecules that are targeting important and likely druggable proteins from the SARS-CoV-2 proteome. Our strategy is to work with natural product (NP) compounds, as represented by plant and animal secondary metabolites, and with chemical that are minor synthetic modifications of natural compounds. Natural products have chemical structures that have been subjected to long periods of biosynthetic natural selection in order to perform highly selective functions and have been the source of most of the known drug compounds leading into the last century. The development of synthetic drugs to treat disease, culminating in the introduction of rational drug design, has been one of the crowning achievements of modern scientific advancement. Despite this progress, compounds that result from the combined efforts of $d e$ novo design and synthesis and combinatorial 
chemistry in modern drug discovery typically suffer problems with toxicity, off-target interactions, ADME (Absorption, Distribution, Metabolism and Excretion), and pharmacokinetic/pharmacodynamics. Natural product structures provide a substantially large and chemically diverse pool of biologically active compounds that have been fit to purpose through natural selection. As such, these compounds represent structures that frequently avoid many of the adverse biological effects observed with synthetic compounds. Furthermore, in periods of relative drought in terms of newly developed synthetic drug compounds, natural products periodically see a resurgence in popularity for drug discovery. With the number of new drug approvals (NDAs) and biologics license applications (BLAs) by the Food and Drug Administration in steady decline over the past several years (taken together, these were down 19\% in 2019²), natural products are in an ever more significant position in the drug discovery and development process.

There are quite a number of examples of natural products being used in experimental screens of the other coronaviruses that induce deadly pneumonias in humans, such as SARS-CoV and MERS-CoV. For instance, lycorine, found in the red spider lily, Lycoris radiata, was reported to be a nanomolar inducer of virally-induced cytopathy of SARS-CoV in a high throughput screen of 200 plant extracts ${ }^{3}$. And some low-micromolar natural product inhibitors of SARSCoV papain-like protease, such as tanshinones ${ }^{4}$ and geranylated flavonoids ${ }^{5}$, have also been reported. Natural products were most recently used in a small virtual screen against human Heat Shock Protein A5 substrate-binding domain $\beta^{6}$, which was considered at the time to be one of the sites used by the SARS-CoV2 spike protein as a recognition site, to prevent viral attachment to the host cell.

\section{Structure-based drug discovery and docking.}

A powerful approach to develop drug candidates that are potent and efficient is to work from knowledge of the three-dimensional structure of the protein targets of importance in a particular disease and to identify small molecules that exhibit the desired chemical features needed to bind, or 'dock', to the proteins of interest. These molecular docking calculations essentially predict or estimate the binding free energy of a chemical in a protein. This involves computer programs that position a small molecule in the binding site of the target and evaluate an interaction energy between the small molecule and its protein environment. Traditionally, a structure-based drug design approach uses an X-ray crystal structure for in silico screening (i.e. docking). A recent application of this approach using chemicals from plants has identified already interesting potential modulators of SARS-CoV-2's main protease ${ }^{7}$. However, a growing body of evidence indicates that small molecules bind to a specific conformation dynamically sampled by the protein at ambient temperatures, a concept known as "conformational selection" (the chemical selects a conformation of the protein to bind to, among a diverse ensemble of protein substructures). The computational equivalent to conformational selection is called "ensemble docking", in which one uses several structures of a target to give small molecules the opportunity to bind to different protein target conformations. Generating multiple conformations of these macromolecules is computationally intensive and benefits from parallelized and docking software. This approach has been successfully used in our laboratory in the discovery of new molecular effectors against a variety of targets ${ }^{8,9}$, and in particular to inhibit protein:protein complexes $^{10}$, and the superiority of ensemble docking over using a single crystal structurebased docking as has been described ${ }^{11,12}$. A recent use of this approach has suggested possible repurposing against the SARS-CoV-2's spike protein ${ }^{13}$. Simulating in silico such a conformational selection mechanism is much more computationally expensive than what is required for using a single structure, but contemporary massively parallel supercomputers are allowing this approach to become used in drug discovery campaigns. This work uses such a supercomputer - an HPW Cray XC50 supercomputer - to facilitate NP-based drug discovery.

\section{Material and Methods}

\section{Database of natural products}

The COlleCtion of Open NatUral producTs (COCONUT, version 4) database ${ }^{14}$ is a curated database of 423,706 unique natural products compounds, as well as possibly synthetic variations of natural products, assembled from 117 other natural products databases cited in scientific literature since the year 2000. It contains annotations of molecular weight, atom and bond counts, source database, logP, polarizability, polar surface area and an index of natural product likeness ${ }^{15,16}$ for each compound. The current version (4) of the COCONUT database was downloaded as a single SD file from the Zenodo website and split into 423,706 individual SD files. The 2D structure files were then converted to $3 \mathrm{D}$ structures using Open Babel 2.4.117. All of the 3D SD files were then loaded into an MDB database using MOE $2019.01^{18}$ and compounds with molecular weights greater than 600 a.u. filtered out, yielding a set of 340,413 structures. The resulting filtered database was clustered by molecular weight and NPL score (an 
index of natural product likeness $)^{16}$, descriptors then used to select a diverse subset of 49,977 compounds from among the 200 clusters. These structures were then converted to PDBQT files with AutoDockTools (MGLTools 1.5.6) ${ }^{19,20}$ in preparation for molecular docking.

\section{Protein targets.}

The proteases in SARS-CoV-2 are targets of choice in the search for treatments for COVID-19, as there are known HIV-1 and Hepatitis C protease inhibitors in use, indicating the druggability of these targets. The interactions between these inhibitors and the active sites of their target proteases are highly specific and the active sites, themselves, are highly conserved among viral families. The enzyme that cleaves the viral polypeptide into its component non-structural proteins is referred to as the main protease (Mpro) and is essential for viral replication. It is a homodimer with catalytic sites facing away from each other, and away from the dimer interface region. It is highly similar in sequence to the other 3-chymotrypsin-like proteases (3CLpro) found in other coronaviruses, such as SARSCoV $\left(96 \%\right.$ identity) ${ }^{21}$, MERS, and porcine epidemic diarrhea virus (PEDV). The main proteases in Coronaviridae all possess catalytic sites composed of a dyad of cysteine and histidine that work in concert to cleave peptide chains at specific sites, residing in a groove that selectively interacts with primarily aromatic side chains - in much the same way chymotrypsin performs the same function, although using a catalytic triad.

Along with the main protease, the papain-like protease (PLpro) is an essential enzyme in SARS-Co This work uses such a powerful supercomputer to facilitate NPbased discovery, the Cray/HPE Sentinel -2 that lies in the $\mathrm{N}$-terminal region of the much larger multidomain NSP3, and is flanked by other catalytic sites that perform several functions, such as the nearby ADPribose-1"-phosphatase. The crystal structure used in this present work is this $\mathrm{N}$-terminal region that contains the protease and two ubiquitin binding sites involved in the de-ubiquitinylation of host recognition receptors that look for pathogenic macromolecules, interfering with the innate immune response. innate immune response ${ }^{22}$. The catalytic site is that of a classic cysteine protease, consisting of a cysteine-histidineaspartate triad, which resides at the junction of the "palm" and the "thumb" of the larger "hand" domain.

In addition to these two enzymes, we are also targeting in this work the so-called 'spike protein'. This protein studs the surface of the coronavirus membrane and gives the virus the appearance of a crown, or corona, under the electron microscope - hence the name coronavirus. It functions to anchor the virus to the angiotensin-converting enzyme 2 (ACE2) on host cell membranes to start the membrane fusion process and so invade the host cell. The spike protein is also the primary viral feature targeted by host cell antibodies. In order to evade recognition by host immune systems, this protein is partially glycosylated. Since the process of this glycosylation occurs within the host cell and some amount of serendipity is involved in the process, the pattern of glycosylation is not the same for every newly-constructed spike protein. This results in each viral coat looking slightly different to the host immune system, so that one type of antibody may not recognize the same virus twice because of variations in spike glycoslation ${ }^{23,24}$.

\section{Protein target conformational ensembles}

Structures for the spike protein, main protease and papain-like protease were obtained from the freely available molecular dynamics simulation coordinate files from the Oak Ridge National Laboratory \& collaborating laboratories SARS-CoV-2 webpage (https://coronavirus-hpc.ornl.gov/data/). These structures are representative conformations clustered from the trajectories of 100 ns restrained temperature replica exchange molecular dynamics simulations of the proteins ${ }^{13}$ using GROMACS $4.5^{25}$, and starting from the Protein Databank Bank entries 6Y2E (main protease), 6W41 (spike protein) and 6W9C (papainlike protease). The ten most populated conformations from each set of clustered structures were used as an ensemble for molecular docking, with each structure being prepared as individual PDBQT files using MGLTools 1.5.6.

\section{Molecular Docking}

The docking code used in this study was AutoDock Vina ${ }^{26} 1.1 .2$, which was compiled from source for use on the Sentinel system in a massively parallel manner. Docking boxes were constructed using the AutoDock plugin for Open Source PyMOL ${ }^{27}$ 1.8.4.0. In the case of the spike protein, a large box containing the entire ACE2 receptor binding domain (RBD), referencing PDB ID: 6VW1, was constructed. For the two proteases, smaller boxes were located around their catalytic sites, with a larger region including the S1 and S2 sites in the binding groove of the main protease. Scripts were used to submit large numbers of individual docking jobs to the Sentinel queue with a Vina exhaustiveness value of 10 and a maximum number of returned poses per docking run of 10 .

\section{Supercomputing}

This work was performed on Sentinel, an HPE Cray XC50 single cabinet supercomputer located in the Microsoft Azure public cloud data center. Sentinel is a 48-node system, featuring 1920 physical Intel Skylake cores operating at $2.4 \mathrm{GHz}$ with $192 \mathrm{~GB}$ ram per node. 
The XC50 utilizes the Aries interconnect ${ }^{28}$ in a Dragonfly topology. These systems have SMT/HT enabled, resulting in 3840 effective CPU cores. A shared 612 TB Cray HPE ClusterStor-based parallel file system is mounted on every node. The Altair PBS Pro scheduler is used for workload distribution.

Autodock Vina 1.1.2 was obtained from the download site (http://vina.scripps.edu/download.html). The code was updated to use the $\mathrm{C}++$ Boost library (https://www.boost.org), version 1.65. Autodock Vina was statically compiled on an Ubuntu 18.04 Linux system utilizing the GCC 8.4.0-1ubuntu1 compiler. The Makefile C_OPTIONS variable, specifying the compiler options, was set to

-03 -DNDEBUG -fpermissive -march=skylake -mtune=skylake -mavx2 -maligndata $=$ cacheline

\section{Pharmacophore analysis}

The top 500 unique natural product poses for each protein target were retained for further evaluation. In each case, the docking scores for the top 500 poses showed no correlation with molecular weight, which indicates no particular bias of the score with respect to the size of the chemicals. Compounds that appeared more than once in the top 500 unique compound lists for Mpro, PLpro and spike protein were considered promiscuous and removed from each list. In addition, compounds that exhibited more than one violation of the Lipinski "drug-likeness" criteria, as calculated with the MOE "drug-like" molecular descriptor, were not included in the final lists of results. The number of compounds that fulfilled the above criteria, i.e., i) appeared in the top 500 docking scores of only one of the three proteins and ii) predicted to be "drug-like" is: 204 compounds for papain-like protease, 232 compounds for the spike protein, and 164 compounds for the main protease. Of these, the top 100 natural products were superimposed on their respective predicted protein targets binding locations in which they were predicted to bind. The compounds that were found to dock to the correct binding site (i.e., in the active sites of the main protease and of the papain-like protease, and on the ACE2/spike protein interface) were kept for pharmacophoric analysis. This analysis was performed using the program MOE and identified the chemical features that at least $25 \%$ of the natural products exhibited in common in corresponding binding sites.

\section{Results and Discussion}

Performance of Vina on Sentinel
A preparation and an initial run script were written that enabled users to create and enqueue jobs. Each Vina calculation required less than 90 seconds to run on a single processor. With a test set of 12,000 calculations, running these jobs serially would have required approximately $1.08 \times 10^{6}$ seconds, approximately 12.5 days. Running across $10 \mathrm{CPU}$ cores, we did see on average, an 8x speedup over a single CPU core. This parallelism combined with the above updated options, enabled us to complete a single calculation in approximately 6 seconds. For the 12,000 calculations, this would require approximately 72,000 seconds or 20 hours of wall clock time to complete on a single node. Over 48 nodes, we measured approximately 271 seconds for a $1 \%$ sample, or 120 runs. Typical supercomputing workloads are long running, parallel calculations, for a single large distributed task. Given that the Autodock Vina code required so few resources per calculation, yet there were many of the calculations, we adapted the supercomputer run environment to enable multiple simultaneous calculation runs per node. After this alteration, and using a modified calculation launch code, we were able to complete all 12,000 calculations in 468 seconds, or approximately 7 minutes, 48 seconds wall clock. This would work out to 25.6 calculations completed per second across the Sentinel XC50 machine. Over the course of 1 day of run time, this could provide approximately $2.22 \times 10^{6}$ calculations per wall clock day. With around 20 protein targets, running 20,000 ligand compounds against these targets would require about $4 \times 10^{5}$ calculations. This approach would require approximately 4.33 wall clock hours, or 15,600 seconds. In comparison with the original calculation mechanism provided by the $\mathrm{UAH}$ team, this would have required roughly $3.6 \times 10^{7}$ seconds, or slightly more than a single CPU-year of calculation time. Running on 10 processor cores, this would have reduced the original run mechanism to $4.5 \times 10^{6}$ seconds, or 1.7 months of run time. This work was faster by about 288 times. There is room for additional improvement, not simply in optimizing Vina, but environmental optimization, algorithmic shifts, and work with additional tools to reduce the search space, but these improvements were not needed to achieve the desired calculations in time and will be developed in the future.

\section{Docking results.}

The docking outputs against each set of target conformations were combined and ranked by docking score. Duplicate instances of each compound were removed from the pose list, retaining only the poses with the best docking score for each compound. Computational approaches to describing physicochemical and structural properties that are 
common to natural product compounds, or those that distinguish them from other classes of compounds - in a manner similar to drug-likeness - have been described in the literature over the past couple of decades. One such description of natural-productlikeness that appears in the COCONUT database derives from common chemical substructures and atom-centered fragments among the compounds in the Dictionary of Natural Products ${ }^{29}$. The resulting NPlikeness score ${ }^{15}$ ranges from a value of -5 to one of +5 , with +5 being the most structurally similar to compounds in the DNP. The use of such a score was suggested by the authors to be useful in the virtual screening of large chemical databases. Here, we used this score as a descriptor for clustering our diverse subset of the COCONUT database into classes of natural products (SI tables). In our diverse subset, these values range from -3.1 to 4.7 , which covers the same range of values found in the complete database. The natural products predicted to be the most promising potential hits against the protein targets in the desired binding sites (see below) have NP-likeness scores that range between -0.8 to +2.9 , with a distribution centered about an NP likeness score of 0.5 .

\section{Papain-like protease}

Figure 1 shows the location of the top 100 compounds fulfilling the criteria above in the papain-like protease target. The compounds can be divided in two clusters, shown respectively in green (40 compounds) and blue (60 compounds) in Figure 1. These two clusters are located on two different sides of the protein, separated by a beta-sheet that is roughly between Asp164 and ALA249 on one side (green cluster), and that incorporates the binding site residues Cys111 and

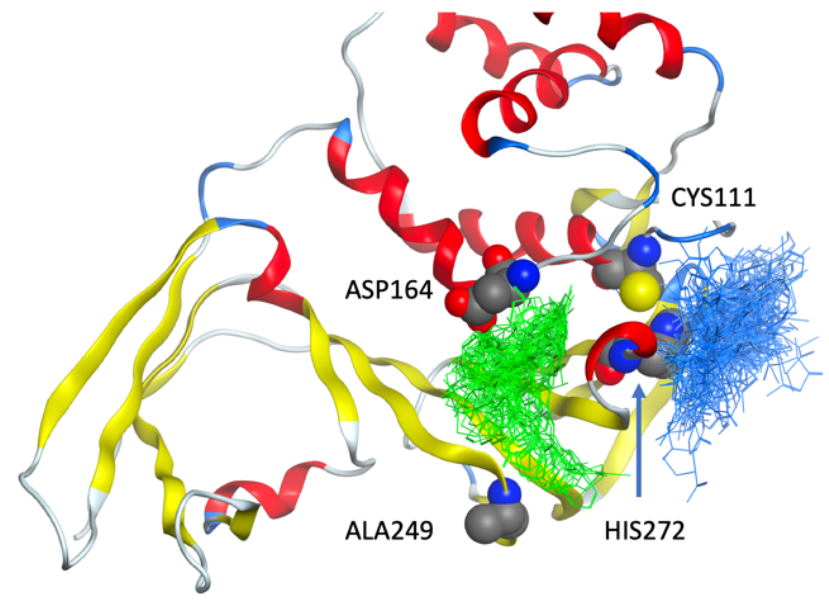

Figure 1. Top-scoring docked natural products on the papain-like protease.

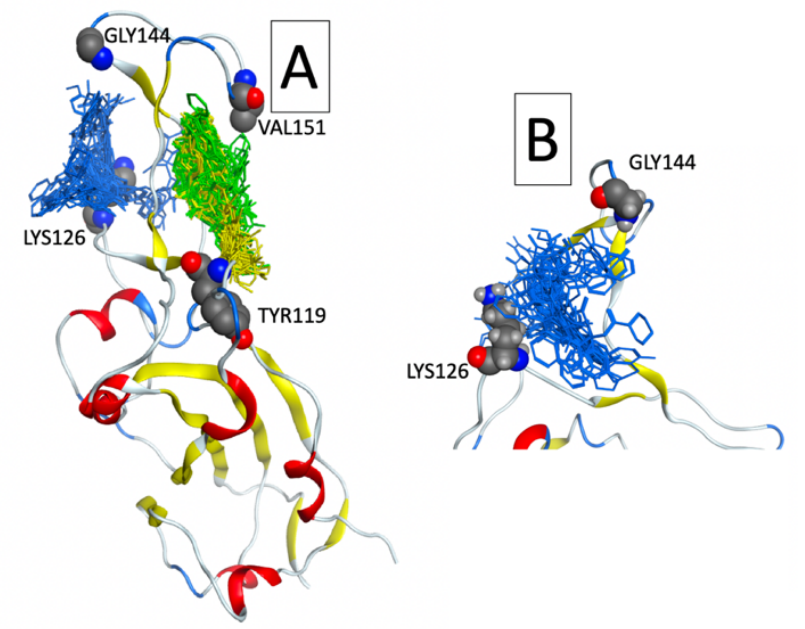

Figure 2. Top-scoring docked natural products on the spike protein.

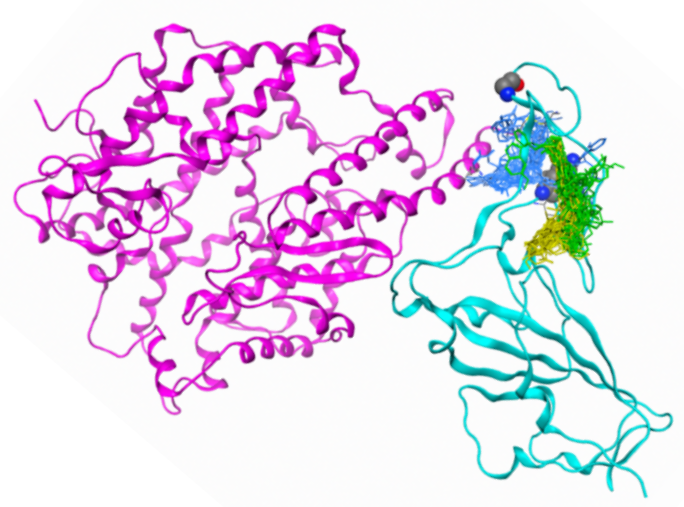

Figure 3. Cluster of of docked molecules from Figure 2 shown on top of the spike protein (cyan) : ACE2 protein (purple) complex.

His272 on the other side (blue cluster). The active site of this target corresponds to the location populated by the blue cluster of docked natural products.

\section{Spike protein}

Figure 2 shows the location of the docked compounds in the spike protein target. As in the case of docking in the papain-like protease, two clusters of compound locations were obtained, located on two different sides of the loop that interacts with the ACE2 receptor: the blue cluster (24 compounds), located in a region roughly defined as between Glu144 and Lys216, and the green/yellow cluster (73 compounds), located on the other side of the loop, in a region roughly defined by the residues Tyr119 and Val151. Figure 3 shows the interface between the spike protein (cyan protein 
backbone) and the ACE2 receptor (purple protein backbone). The blue cluster of docked compounds shown on Figure 2 is located between the two proteins of the spike:ACE2 receptor complex, and hence is likely to disrupt the protein-protein interactions between the two. On the other hand, the green/yellow cluster does not exhibit any molecule that would lead to steric clashes between the spike and the ACE2 proteins.

\section{Main protease}

Figure 4 shows the locations of the docked compounds in the main protease target. In contrast to the docked positions in the spike and papain-like protein targets, the docking locations in the main protease exhibit several different potential docking locations of the natural products (colored greed, blue, yellow, pink and orange on Figure 4). The green cluster (41 molecules) is located the closest to the catalytic site CYS145, and compounds binding in that location would potentially act as inhibitor of the enzyme by blocking or hindering substrate access.
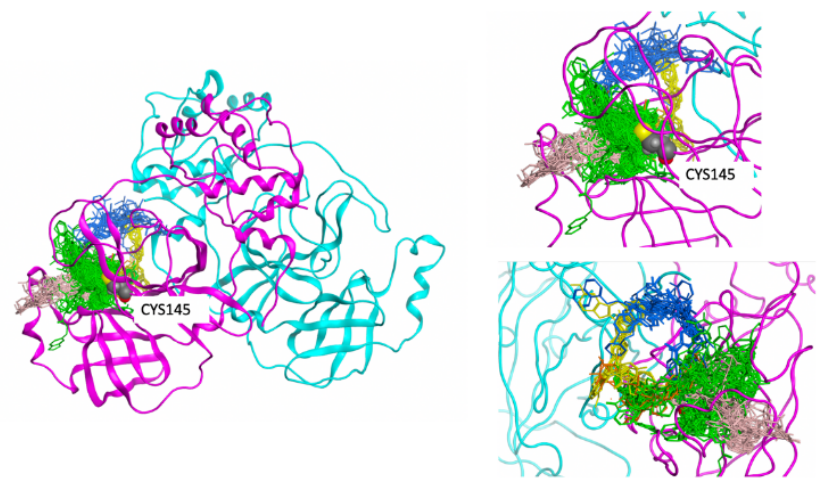

Figure 4. Top-scoring docked natural products in the main protease.

\section{Pharmacophore analysis}

The compounds binding to the desired locations in the proteins, as shown in the figures above, were analyzed to identify common pharmacophore features using the program MOE as described in Methods.

\section{Papain-like protease}

A pharmacophore analysis of the commonalities between the compounds docked in the active site of the papain-like protease is shown in Figure 5a. There are relatively few common regions identified as common between the compounds: a large region (orange wireframe sphere labeled "A" in Figure 5a) represents a resonant and/or hydrophobic group present within that sphere in $45 \%$ of the natural products predicted to bind well in the protein's active site. A region (orange solid sphere labeled "B" on
Figure 5a) indicates the perpendicular to the resonant plane found in $29 \%$ of the binding natural products. The other perpendicular to that resonant plane of region $A$ would be the HIS 272 residue, suggesting that resonant-resonant interactions between this histidine residue and ligands are important for binding of natural products in this active site. Another hydrophobic/resonant region, indicated by the red solid sphere in Figure $5 \mathrm{a}$, is found in $42 \%$ of the natural

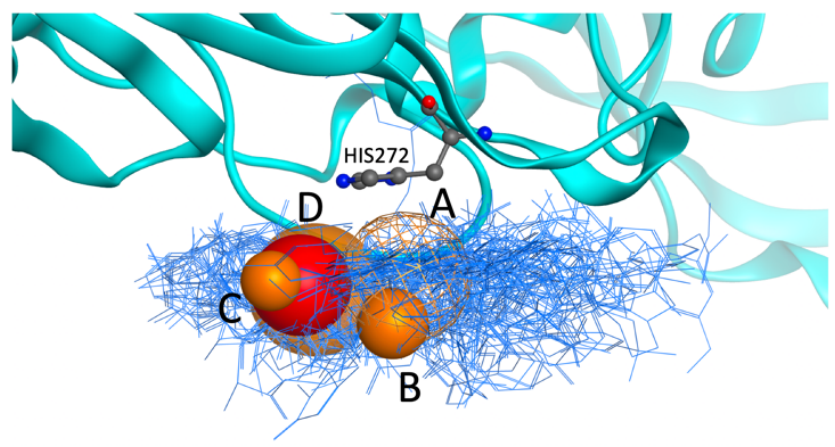

Figure 5a. Pharmacophore features of the natural compounds predicted to bind to the papain-like protease's active site and corresponding to the blue cluster of molecules on Figure 1.

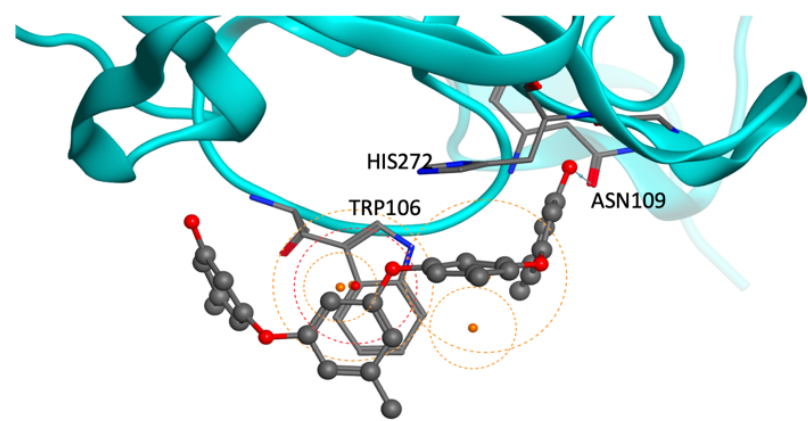

Figure 5b. Example of natural products docked to the papain-like protease's active site and fulfilling the pharmacophore binding motif of Figure $5 \mathrm{a}$.

products binding in the site. The perpendiculars to the resonant plane, labelled $C$ and $D$ in Figure $5 a$, and present in $29 \%$ and $47 \%$ of the ligands, respectively, are also common features of the natural products predicted to be potential ligands and inhibitors of that protein. These commonalities of resonant / hydrophobic moieties found in ligands does not mean that the natural products predicted to bind well in that protein regions must be entirely hydrophobic, and indeed they are not. 
Figure $5 b$ shows an example of a top-scoring natural product in the binding site of the papain-like protease active site. This compound, tetraorcinol $A$, is found in the coral-associated fungus Aspergilus versicolor LCJ5-4 and has been reported to be a free radical scavenger ${ }^{30}$. Tetraorcinol $A$ fits the pharmacophore description of Figure $5 \mathrm{a}$, with a resonant-resonant interaction between the central benzene of the natural compound and Trp106 from the enzyme, with the location of the second benzene ring and of its perpendicular in the other resonant orange pharmacophore / normal to the resonant plane regions. In addition, this compound has two terminal hydroxyl groups, one of them making a hydrogen bond with the backbone's carbonyl of Asn109.

\section{Spike protein}

Figure $6 a$ shows the most common pharmacophore features of the compounds predicted to bind well on the spike protein's regions corresponding to the blue
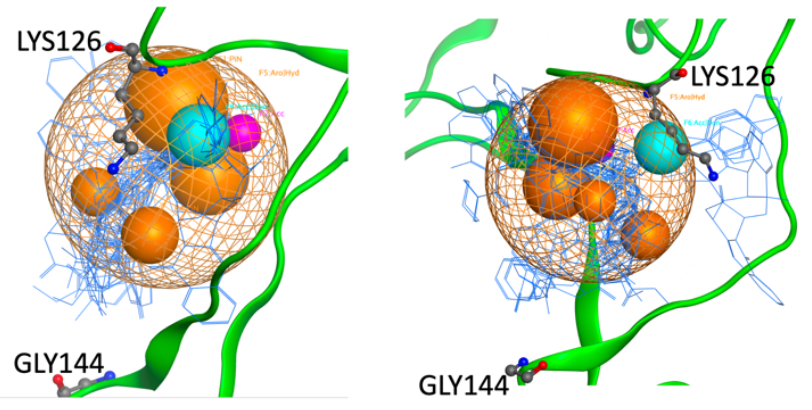

Figure 6a. pharmacophore features of the natural compounds predicted to bind to the spike protein and corresponding to the blue cluster on Figure 3. Right side is rotated 45 degrees from Left side.

cluster of Figures $2 \& 3$, i.e., predicted to disturb the interactions between the spike protein and the ACE2 receptor. As in the case of the papain-like protease results, a large region (orange wireframe sphere in Figure 6a) represents a resonant and/or hydrophobic group present within that sphere in $96 \%$ of the compounds. Inside that large region, 4 spheres (solid orange sphere on Figure 6a) contain the perpendiculars to resonant rings of the compounds (of $83 \%$ of the compounds for the larger orange solid sphere in Figure $6 \mathrm{a}$, and $79 \%, 46 \%$ and $29 \%$ for the three next large orange spheres, respectively.). In addition to the resonant/hydrophobic features, $39 \%$ of the compounds exhibit a hydrogen bond donor or a hydrogen bond acceptor within the location of the cyan solid sphere, and $26 \%$ of the compounds exhibit a hydrogen bond acceptor within the location of the purple sphere. Figure $6 b$ shows the details of a topscoring natural product that fits this pharmacophore description. This compound, prekinamycin, belonging to the kinamycin class of diazofluorene antitumor antibiotics first isolated from the bacteria Streptomyces murayamaensis ${ }^{31-34}$, exhibits hydrogen bonds between its diazo moiety and the amine of Lys216, and between one of its carbonyls and the amine group of Arg122 (Figure 6b, left). Prekinamycin also fulfills the hydrophobic pharmacophore regions, making resonant interactions with Phe124 and Tyr141, and surrounded in a hydrophobic environment defined by
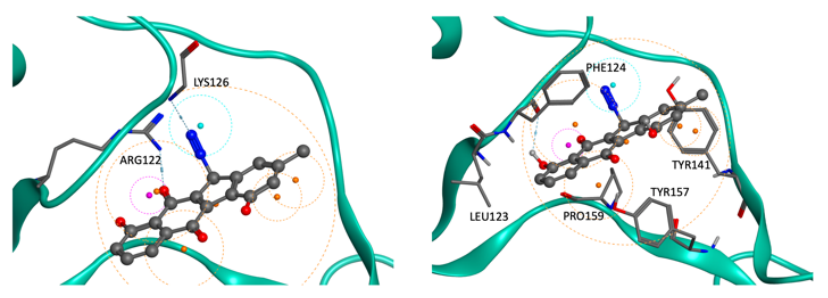

Figure 6b. Example of natural product docked in the spike protein and fulfilling the pharmacophore binding motif of Figure 6a.

\section{the residues Leu123, Pro159 and Tyr157.}

Main protease

Figure 7 shows the most common pharmacophore features of the compounds predicted to bind well in the main protein's catalytic region (close to CYS145). A large region of the binding site corresponds to a large region (largest orange solid sphere in Figure 7) representing a resonant and/or hydrophobic group in $58 \%$ of the compounds. Next to that region, another region (second largest orange solid sphere in Figure 7) contains other resonant and/or hydrophobic groups for $53 \%$ of the natural products predicted to bind in that active site. The semi-transparent blue sphere contains

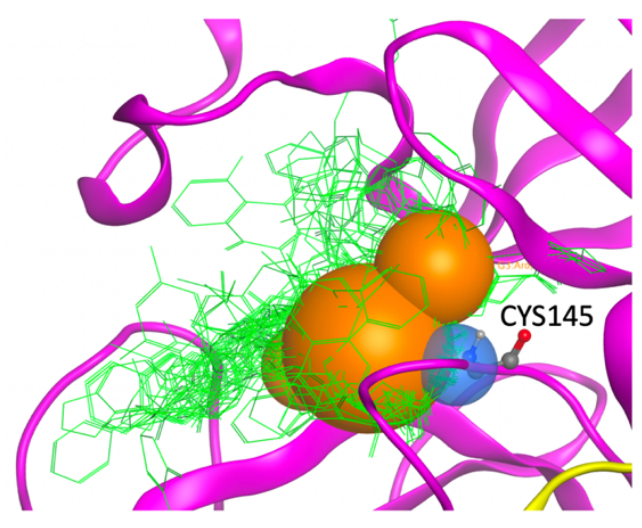

Figure 7. Pharmacophore features of the natural compounds predicted to bind to the main protease active site and corresponding to the green cluster on Figure 4. 
hydrogen bond acceptors or donors for $47 \%$ of the natural products binding in the active site, and $34 \%$ of the compounds are contained in a region perpendicular to a resonant ring in the third largest orange solid sphere. In addition to the resonant/hydrophobic features, $39 \%$ of the compounds exhibit a hydrogen bond donor or a hydrogen bond acceptor within the location of the cyan solid sphere, and $26 \%$ of the compounds exhibit a hydrogen bond acceptor within the location of the purple sphere.

\section{Chemical space of the computational hits}

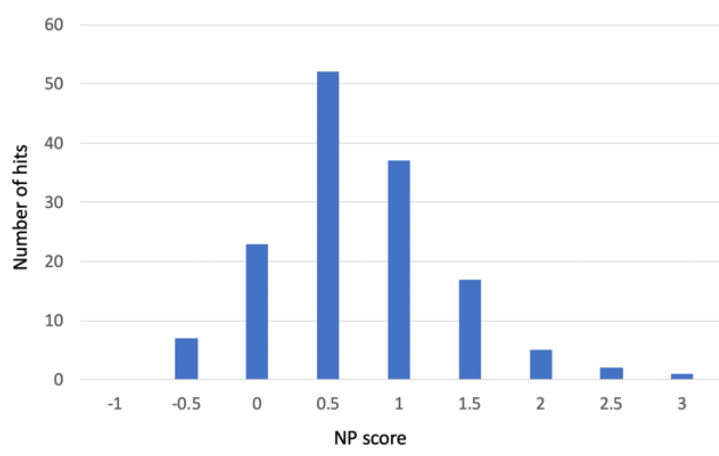

Figure 8. Distribution of NP scores in the top scoring natural products predicted to bind at the desired sites.

The distribution of NP scores in the 144 hits given in SI tables and figures is shown on Figure 8. The distribution of scores across all known natural products exhibit higher populations in the $\sim 0.5-1$ range of scores with the most populated bin of NPL score ${ }^{15}$ having a value of 1 , with the next most populated bin at an NP value of 0.5 . This finding is comparable to what is seen here, albeit in this work the most populated bin is at a NP score of 0.5 and the second most populated bin is for NP score value of 1 . The NP scores for the compounds in the entire COCONUT database range from -3.08 to 4.67 , (Figure SI-1).

\section{Conclusions}

Several compounds from a diverse subset of the largest natural products database currently available have been identified as potential inhibitors of the three most significant targets in the SARS-CoV-2 proteome, CLpro, PLpro and the spike protein receptor-binding domain. The compounds are within the natural product chemical space, are relatively diverse structurally, although they share common chemical features as described in the pharmacophore analysis. The common chemical features suggest that the natural product that are predicted to bind the best to the protein targets exhibit a largely hydrophobic center, with a preference for aromatic moieties, and some hydrogen bond acceptors/donors on the periphery of this resonant core. Many of the top-scoring compounds that fulfill these criteria exhibit a mix of fused rings and heterocyclic rings, e.g. (but not limited to) flavonoids, and a relatively high diversity of location and nature of hydrophilic attachments. We list below some of the compounds for which organismal and/or health indications could be retrieved from the COCONUT database.

Several structures found in the virtual screen of the main protease also matched at least 4 of the 6 features of the Mpro pharmacophore. One of these structures is Cassiarine E [CNP0328498], which is found in the cassia tree Cassia siamea, which is used in traditional medicines in Burma and Thailand. The medicinal value of the extract of this plant is attributed to a related compound, barakol, which has sedative and anxiolytic properties ${ }^{35,36}$. These structures belong to a class of pyranoisoquinolines known as Cassiarines (A-J), which are also found in the extracts of the Cassia family ${ }^{37}$. Yet another compound predicted to be potentially binding to the main protease is 5,6-dihydro, 5a-chloro-6 $\beta$-hydroxy-Jaborosalactone

[CNP0252890], one of several jaborosalactones ${ }^{38}$; naturally-occurring Withanolide chlorohydrins found in the extracts of species in the genus Jaborosa that have been reported to act as insect anti-feedants ${ }^{39}$. These plants are members of the Solanaceae family and are widely distributed throughout South America, but primarily in the Andes region. 45,3-dichloro1(1,2),2(1,4),4,5(1,3)-tetrabenzenacycloheptaphane$2^{3}, 4^{4}, 5^{6}$-triol [CNP0273258], also known as 12,10'dichloroisoplagiochin $\mathrm{C}^{40}$ is found in Japanese liverwort Herbertus sakuraii. Kadcoccilactone G [CNP0363620] is among several other Kadcoccilactones ${ }^{41}$ found in Kadsura coccinea. This genus of climbing plant is found throughout southeast Asia, where $K$. coccinea itself is used in cuisine and traditional medicine to treat gastric and duodenal ulcers, gastroenteritis, rheumatism, lumbago, and dysmenorrhea ${ }^{42}$. Aspertryptanthrin B [CNP0110880], is found in several terrestrial and marine species in the genus Aspergillus, but it has not been shown to have biological activity, although many other indole diketopiperazines from this genus have reported cytotoxic effects ${ }^{43}$.

Several of the natural products predicted to bind in the papain-like protease's active site possess a tetrahydropyran ring. Structures found in the virtual screen of the papain-like protease that matched at least 3 of the 5 features of the pharmacophore were also recovered. In addition to tetraorcinol A, 6hydroxystaurosporinone [CNP0301743] is isolated from the myxomycete Lycogala Epidendrum, and has been reported to be a protein tyrosine kinase 
inhibitor ${ }^{44}$. Asperlicin D [CNP0245001], isolated from the fungus Aspergillus alliaceus, is in the family of mycotoxins known as Asperlicins ${ }^{45,46}$ that have been shown to be selective antagonists for the cholecystokinin receptor $\mathrm{CCK}_{A}^{47,48}$. 1-hydroxy-4phenethyl-2-((3,4,5-trihydroxy-6-(1-

hydroxycyclohexyl)tetrahydro-2H-pyran-2-

yl)oxy)anthracene-9,10-dione [CNP0420259], is a 1,2dihydroxyanthraquinone glycoside. Many naturallyoccurring anthraquinone derivatives have been shown to exhibit antibacterial and antitumor activity. For instance, deoxy-2,3,3'4',6,7-hexahydro-8-(2,2dimethyl-2H-benzopyran-6-yl)-5-hydroxy-2,2dimethyl-2H,6H-benzo[1,2-b:5,4-b']dipyran-6-one ${ }^{49}$ [CNP0292046] is a flavonoid found in the leaf extract of Artocarpus fulvicortex, a fruiting tree from Indonesia and Malaysia. Flavonoids isolated from this genus have been shown to have medicinal properties, such as antiplatelet ${ }^{50,51}$, antimicrobial ${ }^{52}$, anti-inflammatory ${ }^{53}$ and cytotoxic effects ${ }^{54}$.

Among the natural products predicted to bind to the spike protein in a way that would disrupt its interaction with ACE2, polyphenols and in particular flavonoids, are seen in several computational hits. In particular, compounds based at least in part on apigenin scaffolds are observed. Apigenin, interestingly, is hypothesized to regulate the expression of ACE2 ${ }^{55}$. Apigenin is found in many plants, and is particularly abundant in the flowers of the chamomile plants. In addition to prekinamycin $A$, which has been reported in the literature to exhibit cytotoxicity to human leukemia cells $^{34}$, harunganin [CNP0334196], isolated from the dragon's blood tree, Harungana madagascariensis, from Madagascar and several nearby countries in Africa, where the extracts have been used in traditional medicines to treat a variety of ailments such as dysentery, diarrhea, anemia, typhoid and heart ailments $^{56}$. Beccamarin ${ }^{57,58}$ [CNP0132136] was also found to fit the pharmacophore. This compound is found in the bark of the ironwood tree, Mesua beccariana, whose extract has been used in traditional medicine to treat fever, renal diseases, poultice and dyspepsia in Malaysia. Beccamarin has recently been shown to inhibit the proliferation of the Raji (lymphoma), SK-MEL-28 (malignant melanoma cells) and HeLa (cervical cells) human cancer cell lines ${ }^{59}$.

This list can be the basis of an experimental validation for target engagement and against SARS-CoV-2's three proteins studied here, and for phenotypic effect. The pharmacophore models derived here from the docking calculations will be used in a subsequent screening of the entire Coconut database, as well as for extremely large databases of chemicals outside of the natural products space.

\section{Acknowledgements}

We wish to thank Ryan Yates, Amar Chittiboyana and Anna Petroff for useful discussions. We thank the HPE Strategic Alliance and Communication teams for facilitating this work, in particular Joseph George, Alison Paisley, Paul Rosien and Rangan Sukumar. 


\section{References}

(1) Pushpakom, S.; lorio, F.; Eyers, P. A.; Escott, K. J.; Hopper, S.; Wells, A.; Doig, A.; Guilliams, T.; Latimer, J.; McNamee, C.; et al. Drug Repurposing: Progress, Challenges and Recommendations. Nat. Rev. Drug Discov. 2019, 18 (1), 41-58.

https://doi.org/10.1038/nrd.2018.168.

(2) GlobalData. FDA new drug approvals down

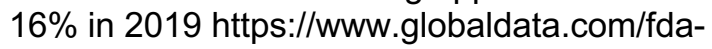
new-drug-approvals-down-16-in-2019/.

(3) Li, S. Y.; Chen, C.; Zhang, H. Q.; Guo, H. Y.; Wang, H.; Wang, L.; Zhang, X.; Hua, S. N.; Yu, J.; Xiao, P. G.; et al. Identification of Natural Compounds with Antiviral Activities against SARS-Associated Coronavirus. Antiviral Res. 2005, 67 (1), 18-23. https://doi.org/10.1016/j.antiviral.2005.02.007.

(4) Park, J.; Hoon, J.; Min, Y.; Jae, H.; Wook, D.; Hun, K.; Kwon, H.; Park, S.; Song, W.; Bae, Y. Tanshinones as Selective and Slow-Binding Inhibitors for SARS-CoV Cysteine Proteases. Bioorg. Med. Chem. 2012, 20 (January), 59285935.

(5) Keun, J.; Curtis-long, M. J.; Ho, K.; Wook, D.; Won, H.; Joo, H.; Hun, K. Geranylated Flavonoids Displaying SARS-CoV Papain-like Protease Inhibition from the Fruits of Paulownia Tomentosa. Bioorg. Med. Chem. 2013, 21, 3051-3057.

(6) Elfiky, A. A. Natural Products May Interfere with SARS-CoV-2 Attachment to the Host Cell. J. Biomol. Struct. Dyn. 2020, 0 (0), 1-16. https://doi.org/10.1080/07391102.2020.176188 1.

(7) Tahir ul Qamar, M.; Alqahtani, S. M.; Alamri, M. A.; Chen, L.-L. Structural Basis of SARS-CoV-2 3CLpro and Anti-COVID-19 Drug Discovery from Medicinal Plants. J. Pharm. Anal. 2020. https://doi.org/https://doi.org/10.1016/j.jpha.202 0.03.009.

(8) Abdali, N.; Parks, J. M.; Haynes, K. M.; Chaney, J. L.; Green, A. T.; Wolloscheck, D.; Walker, J. K.; Rybenkov, V. V; Baudry, J.; Smith, J. C.; et al. Reviving Antibiotics: Efflux Pump Inhibitors That Interact with AcrA, a Membrane Fusion Protein of the AcrAB-TolC Multidrug Efflux Pump. ACS Infect. Dis. 2017, 3 (1), 89-98.

https://doi.org/10.1021/acsinfecdis.6b00167.
(9)

Velazquez, H. A.; Riccardi, D.; Xiao, Z.; Quarles, L. D.; Yates, C. R.; Baudry, J.; Smith, J. C. Ensemble Docking to Difficult Targets in Early-Stage Drug Discovery: Methodology and Application to Fibroblast Growth Factor 23. Chem. Biol. Drug Des. 2018, 91 (2), 491-504. https://doi.org/10.1111/cbdd.13110.

(10) Kapoor, K.; McGill, N.; Peterson, C. B.; Meyers, H. V; Blackburn, M. N.; Baudry, J. Discovery of Novel Nonactive Site Inhibitors of the Prothrombinase Enzyme Complex. J. Chem. Inf. Model. 2016, 56 (3), 535-547. https://doi.org/10.1021/acs.jcim.5b00596.

(11) Amaro, R. E.; Baudry, J.; Chodera, J.; Demir, Ö.; McCammon, J. A.; Miao, Y.; Smith, J. C. Ensemble Docking in Drug Discovery. Biophys. J. 2018, 114 (10), 2271-2278.

https://doi.org/https://doi.org/10.1016/j.bpj.2018. 02.038 .

(12) Evangelista Falcon, W.; Ellingson, S. R.; Smith, J. C.; Baudry, J. Ensemble Docking in Drug Discovery: How Many Protein Configurations from Molecular Dynamics Simulations Are Needed To Reproduce Known Ligand Binding? J. Phys. Chem. B 2019, 123 (25), 5189-5195. https://doi.org/10.1021/acs.jpcb.8b11491.

Smith, M.; Smith, J. C. Repurposing Therapeutics for COVID-19: SupercomputerBased Docking to the SARS-CoV-2 Viral Spike Protein and Viral Spike Protein-Human ACE2 Interface. 2020.

https://doi.org/10.26434/chemrxiv.11871402.v4.

Sorokina, M.; Steinbeck, C. COCONUT: the COlleCtion of Open NatUral producTs http://doi.org/10.5281/zenodo.3778405 (accessed May 28, 2020).

Ertl, P.; Roggo, S.; Schuffenhauer, A. Natural Product-Likeness Score and Its Application for Prioritization of Compound Libraries. J. Chem. Inf. Model. 2008, 48 (1), 68-74. https://doi.org/10.1021/ci700286x.

Sorokina, M.; Steinbeck, C. NaPLeS: A Natural Products Likeness Scorer-Web Application and Database. J. Cheminform. 2019, 11 (1), 55. https://doi.org/10.1186/s13321-019-0378-z.

O'Boyle, N. M.; Banck, M.; James, C. A.; Morley, C.; Vandermeersch, T.; Hutchison, G. R. Open Babel: An Open Chemical Toolbox. J. Cheminform. 2011, 3 (1), 33. 
https://doi.org/10.1186/1758-2946-3-33.

(18) Molecular Operating Environment (MOE) 2019, Chemical Computing Group. Chemical Computing Group: Montreal 2019.

(19) Morris, G. M.; Huey, R.; Lindstrom, W.; Sanner, M. F.; Belew, R. K.; Goodsell, D. S.; Olson, A. J. AutoDock4 and AutoDockTools4: Automated Docking with Selective Receptor Flexibility. J. Comput. Chem. 2009, 30 (16), 2785-2791. https://doi.org/10.1002/jcc.21256.

(20) Sanner, M. F. Python: A Programming Language for Software Integration and Development. J. Mol. Graph. Model. 1999, 17 (1), 57-61.

(21) Zhang, L.; Lin, D.; Sun, X.; Curth, U.; Drosten, C.; Sauerhering, L.; Becker, S.; Rox, K.; Hilgenfeld, R. Crystal Structure of SARS-CoV-2 Main Protease Provides a Basis for Design of Improved a-Ketoamide Inhibitors. Science (80-. ). 2020, 368 (6489), 409-412.

https://doi.org/10.1126/science.abb3405.

(22) Báez-Santos, Y. M.; St John, S. E.; Mesecar, A. D. The SARS-Coronavirus Papain-like Protease: Structure, Function and Inhibition by Designed Antiviral Compounds. Antiviral Res. 2015, 115, 21-38. https://doi.org/10.1016/j.antiviral.2014.12.015.

Ou, X.; Liu, Y.; Lei, X.; Li, P.; Mi, D.; Ren, L.; Guo, L.; Guo, R.; Chen, T.; Hu, J.; et al. Characterization of Spike Glycoprotein of SARS-CoV-2 on Virus Entry and Its Immune Cross-Reactivity with SARS-CoV. Nat. Commun. 2020, 11 (1), 1620. https://doi.org/10.1038/s41467-020-15562-9.

(24) Grant, O. C.; Montgomery, D.; Ito, K.; Woods, R. J. Analysis of the SARS-CoV-2 Spike Protein Glycan Shield: Implications for Immune Recognition. bioRxiv 2020, 2020.04.07.030445. https://doi.org/10.1101/2020.04.07.030445.

(25) Van Der Spoel, D.; Lindahl, E.; Hess, B.; Groenhof, G.; Mark, A. E.; Berendsen, H. J. C. GROMACS: Fast, Flexible, and Free. J. Comput. Chem. 2005, 26 (16), 1701-1718. https://doi.org/10.1002/jcc.20291.

(26) Trott, O.; Olson, A. J. AutoDock Vina: Improving the Speed and Accuracy of Docking with a New Scoring Function, Efficient Optimization, and Multithreading. J. Comput. Chem. 2010, 31 (2), 455-461. https://doi.org/10.1002/jcc.21334.
(27) The PyMOL Molecular Graphics System. Schrödinger, LLC.

Alverson, B.; Froese, E.; Kaplan, L.; Roweth, D. Cray ${ }^{\circledR} X C^{T M}$ Series Network; 2012.

CRC Dictionary of Natural Products, 15.2.; CRC Press: Boca Raton, 2006.

Zhuang, Y.; Teng, X.; Wang, Y.; Liu, P.; Wang, H.; Li, J.; Li, G.; Zhu, W. Cyclopeptides and Polyketides from Coral-Associated Fungus, Aspergillus Versicolor LCJ-5-4. Tetrahedron 2011, 67 (37), 7085-7089.

https://doi.org/https://doi.org/10.1016/j.tet.2011. 07.003 .

Woo, C. M. Synthetic and Chemical Biological Studies of the Diazofluorene Antitumor Antibiotics, Yale University, 2017.

Gould, S. J.; Chen, J.; Cone, M. C.; Gore, M. P.; Melville, C. R.; Tamayo, N. Identification of Prekinamycin in Extracts of Streptomyces Murayamaensis. J. Org. Chem. 1996, 61 (17), 5720-5721. https://doi.org/10.1021/jo9611024.

Hata, T.; Omura, S.; Iwai, Y.; Nakagawa, A.; Otani, M.; Ito, S.; Matsuya, T. A New Antibiotic, Kinamycin : Fermentation, Isolation, Purification and Properties. J. Antibiot. (Tokyo). 1971, 24 (6), 353-359.

Abbott, G. L.; Wu, X.; Zhao, Z.; Guo, L.; Birman, V. B.; Hasinoff, B. B.; Dmitrienko, G. I. Prekinamycin and an Isosteric-Isoelectronic Analogue Exhibit Comparable Cytotoxicity towards K562 Human Leukemia Cells. Medchemcomm 2014, 5, 1364-1370.

Thongsaard, W.; Pongsakorn, S.; Sudsuang, R.; Bennett, G. W.; Kendall, D. A.; Marsden, C. A. Barakol, a Natural Anxiolytic, Inhibits Striatal Dopamine Release but Not Uptake in Vitro. Eur. J. Pharmacol. 1997, 319 (2), 157-164. https://doi.org/https://doi.org/10.1016/S00142999(96)00850-3.

Sukma, M.; Chaichantipyuth, C.; Murakami, Y.; Tohda, M.; Matsumoto, K.; Watanabe, H. CNS Inhibitory Effects of Barakol, a Constituent of Cassia Siamia Lamk. J. Ethnopharmacol. 2002, 83 (1-2), 87-94.

Bondarenko, S. P.; Frasinyuk, M. S. Chromone Alkaloids: Structural Features, Distribution in Nature, and Biological Activity. Chem. Nat. Compd. 2019, 55 (2), 201-234. https://doi.org/10.1007/s10600-019-02656-0. 
(38) Bonetto, G. M.; Gil, R. R.; Oberti, J. C.; Veleiro, A. S.; Burton, G. Novel Withanolides from Jaborosa Sativa. J. Nat. Prod. 1995, 58 (5), 705-711. https://doi.org/10.1021/np50119a008.

(39) Vaccarini, C. E.; Bonetto, G. M. Antifeedant Activity Evaluation of Withanolides from Jaborosa Integrifolia. Molecules 2000, 5 (3), 422-423. https://doi.org/10.3390/50300422.

(40) Hashimoto, T.; Irita, H.; Takaoka, S.; Tanaka, M.; Asakawa, Y. New Chlorinated Cyclic Bis(Bibenzyls) from the Liverworts Herbertus Sakuraii and Mastigophora Diclados. Tetrahedron 2000, 56 (20), 3153-3159. https://doi.org/https://doi.org/10.1016/S00404020(00)00236-2.

(41) Gao, X.-M.; Pu, J.-X.; Huang, S.-X.; Lu, Y.; Lou, L.-G.; Li, R.-T.; Xiao, W.-L.; Chang, Y.; Sun, H.D. Kadcoccilactones A-J, Triterpenoids from Kadsura Coccinea. J. Nat. Prod. 2008, 71 (7), 1182-1188. https://doi.org/10.1021/np800078x.

(42) Saunders, R. M. K. Systematic Botany Monographs, Monograph.; Anderson, C., Ed.; The American Society of Plant Taxonomists: Ann Arbor, 1998; Vol. 54.

Ma, Y.-M.; Liang, X.-A.; Kong, Y.; Jia, B. Structural Diversity and Biological Activities of Indole Diketopiperazine Alkaloids from Fungi. $J$. Agric. Food Chem. 2016, 64 (35), 6659-6671. https://doi.org/10.1021/acs.jafc.6b01772.

(44) Hosoya, T.; Yamamoto, Y.; Uehara, Y.; Hayashi, M.; Komiyama, K.; Ishibashi, M. New Cytotoxic Bisindole Alkaloids with Protein Tyrosine Kinase Inhibitory Activity from a Myxomycete Lycogala Epidendrum. Bioorg. Med. Chem. Lett. 2005, 15 (11), 2776-2780. https://doi.org/10.1016/j.bmcl.2005.03.103.

(45) Chang, R. S.; Lotti, V. J.; Monaghan, R. L.; Birnbaum, J.; Stapley, E. O.; Goetz, M. A.; Albers-Schönberg, G.; Patchett, A. A.; Liesch, J. M.; Hensens, O. D. A Potent Nonpeptide Cholecystokinin Antagonist Selective for Peripheral Tissues Isolated from Aspergillus Alliaceus. Science 1985, 230 (4722), 177-179. https://doi.org/10.1126/science.2994227.

(46) Liesch, J. M.; Hensens, O. D.; Springer, J. P.; Chang, R. S.; Lotti, V. J. Asperlicin, a Novel Non-Peptidal Cholecystokinin Antagonist from Aspergillus Alliaceus. Structure Elucidation. J. Antibiot. (Tokyo). 1985, 38 (12), 1638-1641. https://doi.org/10.7164/antibiotics.38.1638.
Van der Bent, A.; Ter Laak, A. M.; IJzerman, A. P.; Soudijn, W. Molecular Modelling of Asperlicin Derived Cholecystokinin A Receptor Antagonists. Eur. J. Pharmacol. 1992, 226 (4), 327-334. https://doi.org/10.1016/09224106(92)90050-6.

Lattmann, E.; Billington, D. C.; Poyner, D. R.; Howitt, S. B.; Offel, M. Synthesis and Evaluation of Asperlicin Analogues as NonPeptidal Cholecystokinin-Antagonists. Drug Des. Discov. 2001, 17 (3), 219-230.

Jamil, S.; Taher, M.; Sirat, H. M.; Othman, N. A. Flavonoids and Triterpenes from the Leaves of Artocarpus Fulvicortex. Nat. Prod. Commun. 2012, 7 (12), 1587-1588. https://doi.org/10.1177/1934578x1200701211.

Weng, J.-R.; Chan, S.-C.; Lu, Y.-H.; Lin, H.-C.; Ko, H.-H.; Lin, C.-N. Antiplatelet Prenylflavonoids from Artocarpus Communis. Phytochemistry 2006, 67 (8), 824-829. https://doi.org/10.1016/j.phytochem.2006.01.03 0 .

Jantan, I.; Mohd Yasin, Y. H.; Jamil, S.; Sirat, $\mathrm{H}$.; Basar, N. Effect of Prenylated Flavonoids and Chalcones Isolated from Artocarpus Species on Platelet Aggregation in Human Whole Blood. J. Nat. Med. 2010, 64 (3), 365369. https://doi.org/10.1007/s11418-010-04100 .

Kuete, V.; Ango, P. Y.; Fotso, G. W.; Kapche, G. D. W. F.; Dzoyem, J. P.; Wouking, A. G.; Ngadjui, B. T.; Abegaz, B. M. Antimicrobial Activities of the Methanol Extract and Compounds from Artocarpus Communis (Moraceae). BMC Complement. Altern. Med. 2011, 11 (1), 42. https://doi.org/10.1186/14726882-11-42.

Wei, B.-L.; Weng, J.-R.; Chiu, P.-H.; Hung, C.F.; Wang, J.-P.; Lin, C.-N. Antiinflammatory Flavonoids from Artocarpus Heterophyllus and Artocarpus Communis. J. Agric. Food Chem. 2005, 53 (10), 3867-3871. https://doi.org/10.1021/jf047873n.

Chin-Lin, H.; Shyu, M.-H.; Lin, J.-A.; Yen, G.-C.; Fang, S.-C. Cytotoxic Effects of Geranyl Flavonoid Derivatives from the Fruit of Artocarpus Communis in SK-Hep-1 Human Hepatocellular Carcinoma Cells. Food Chem. 2011, v. 127 (1), 127-134-2011 v.127 no.1. https://doi.org/10.1016/j.foodchem.2010.12.100. 
(55) Salehi, B.; Venditti, A.; Sharifi-Rad, M.; Kręgiel, D.; Sharifi-Rad, J.; Durazzo, A.; Lucarini, M.; Santini, A.; Souto, E. B.; Novellino, E.; et al. The Therapeutic Potential of Apigenin. Int. J. Mol. Sci. 2019, 20 (6), 1305.

https://doi.org/10.3390/ijms20061305.

(56) Happi, G. M.; Tiani, G. L. M.; Gbetnkom, B. Y. M.; Hussain, H.; Green, I. R.; Ngadjui, B. T.;

Kouam, S. F. Phytochemistry and

Pharmacology of Harungana

Madagascariensis: Mini Review. Phytochem.

Lett. 2020, 35, 103-112.

https://doi.org/https://doi.org/10.1016/j.phytol.20 19.11.015.

(57) Lian Ee, G. C.; Teh, S. S.; Mah, S. H.;

Rahmani, M.; Taufiq-Yap, Y. H.; Awang, K. A Novel Cyclodione Coumarin from the Stem
Bark of Mesua Beccariana. Molecules 2011, 16 (9), 7249-7255.

https://doi.org/10.3390/molecules16097249.

(58) Karunakaran, T.; Ee, G. C. L.; Tee, K. H.; Ismail, I. S.; Zamakshshari, N. H.; Peter, W. M. Cytotoxic Prenylated Xanthone and Coumarin Derivatives from Malaysian Mesua Beccariana. Phytochem. Lett. 2016, 17, 131-134. https://doi.org/https://doi.org/10.1016/j.phytol.20 16.07.026.

(59) Teh, S. S.; Ee, G. C. L.; Mah, S. H.; Lim, Y. M.; Rahmani, M. Mesua Beccariana (Clusiaceae), a Source of Potential Anti-Cancer Lead Compounds in Drug Discovery. Molecules 2012, 17 (9), 10791-10800. https://doi.org/10.3390/molecules170910791. 


\section{Supplementary Information}

List and Coconut4 IDs of top 37 natural products predicted to be top binders in the MPRO active site

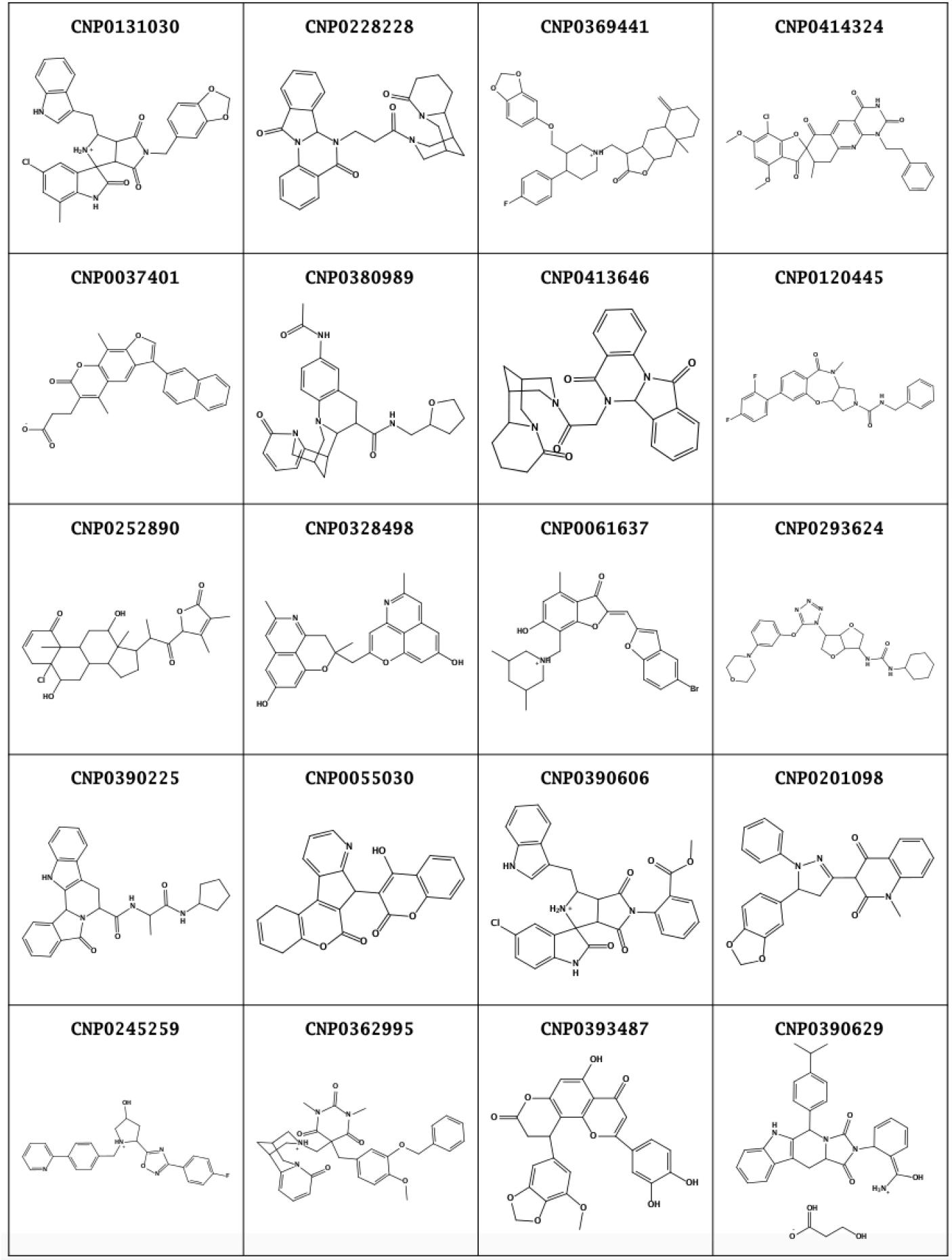




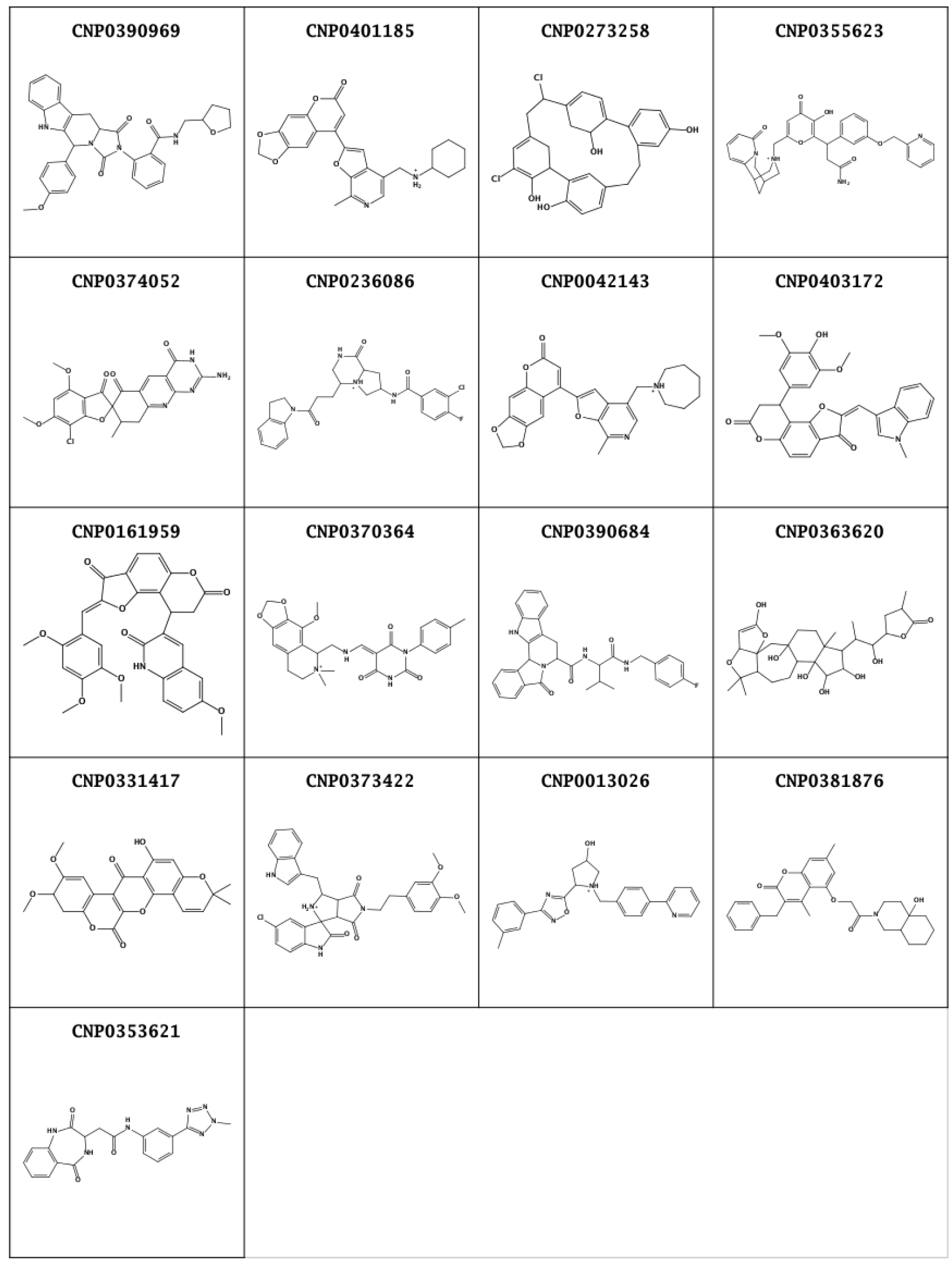


List and Coconut4 IDs of 19 top natural products predicted to be top binders in the spike protein:ACE2 interaction surface

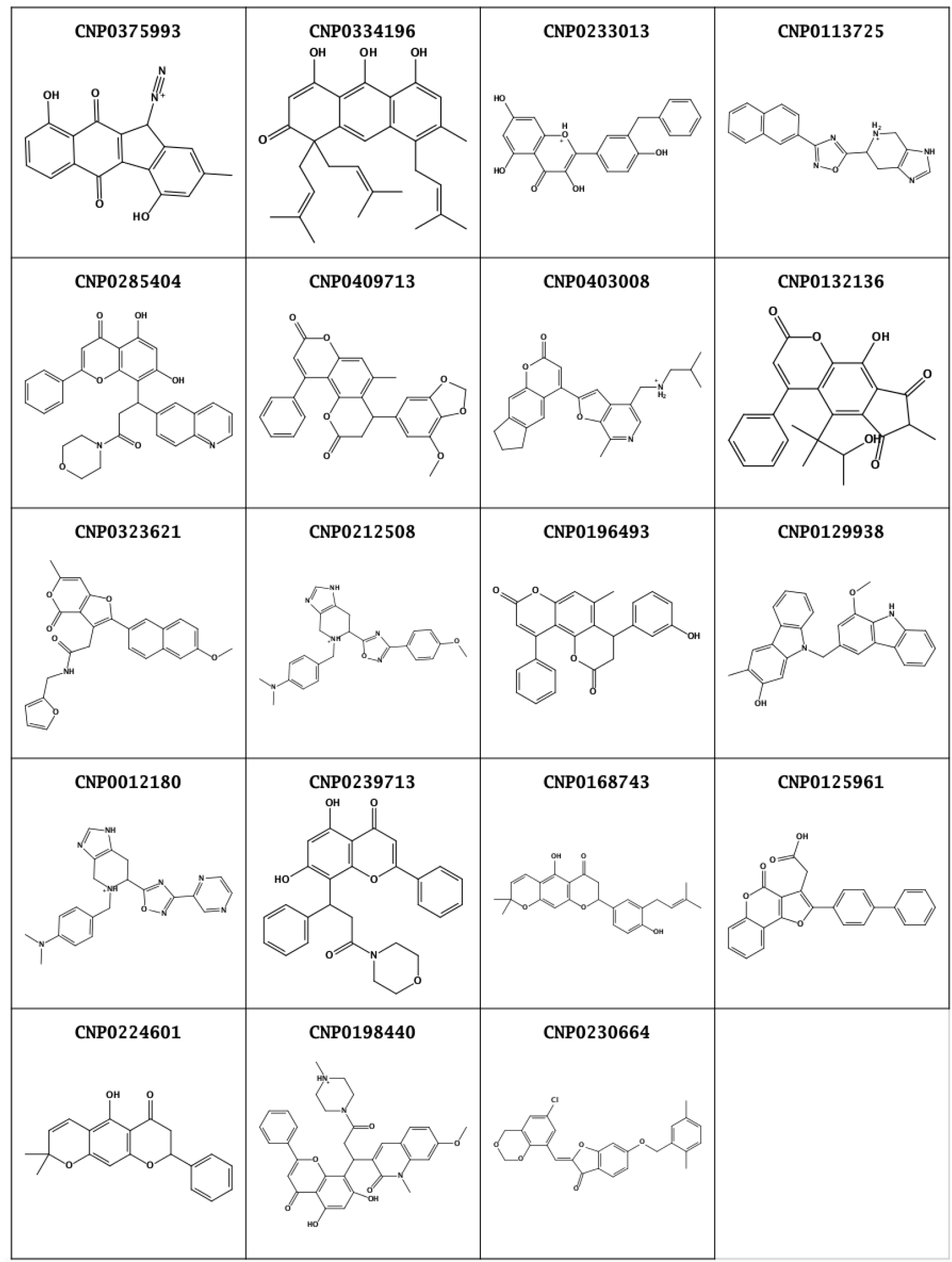


List and Coconut4 IDs of 58 natural products predicted to be top binders in the PLPRO binding site

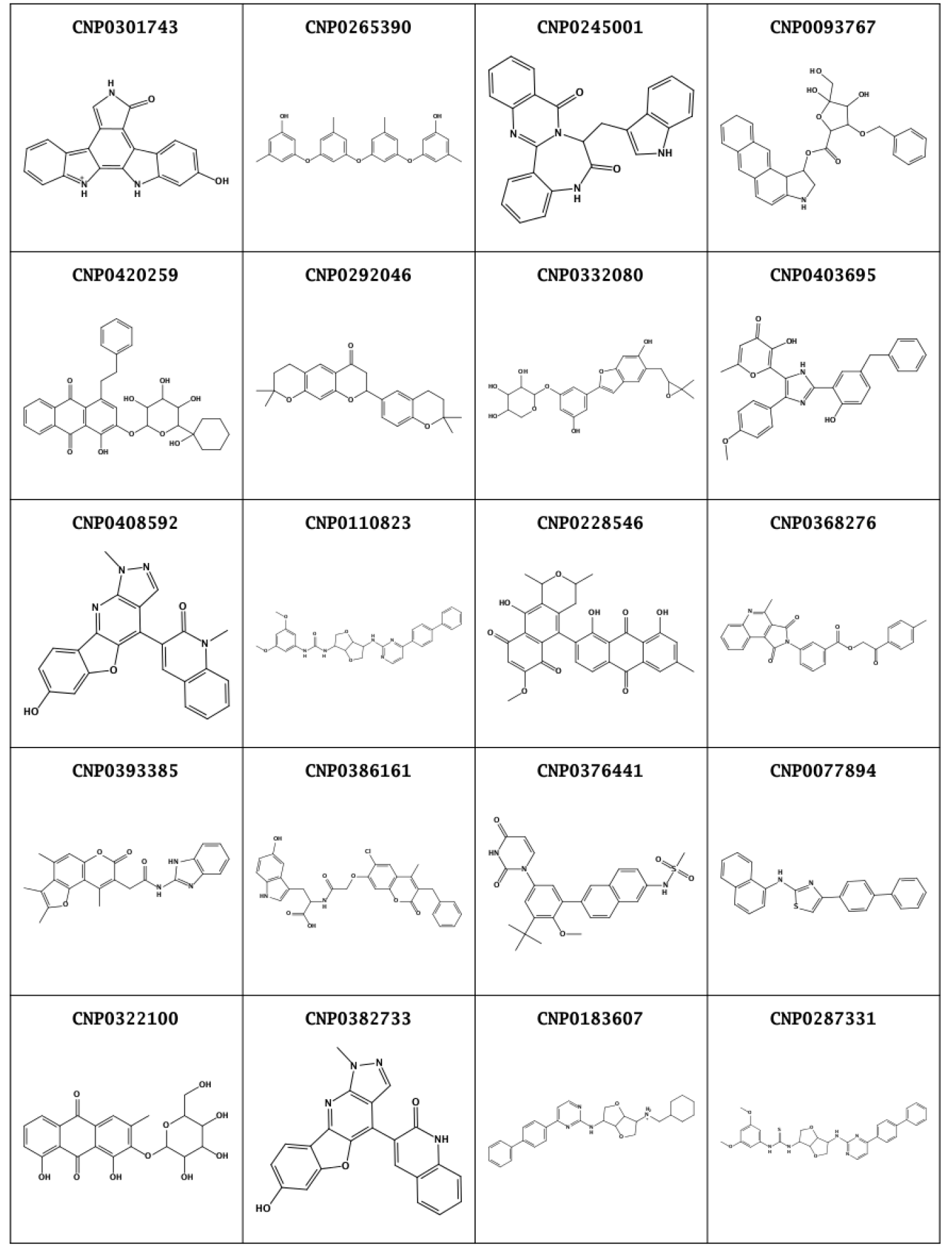




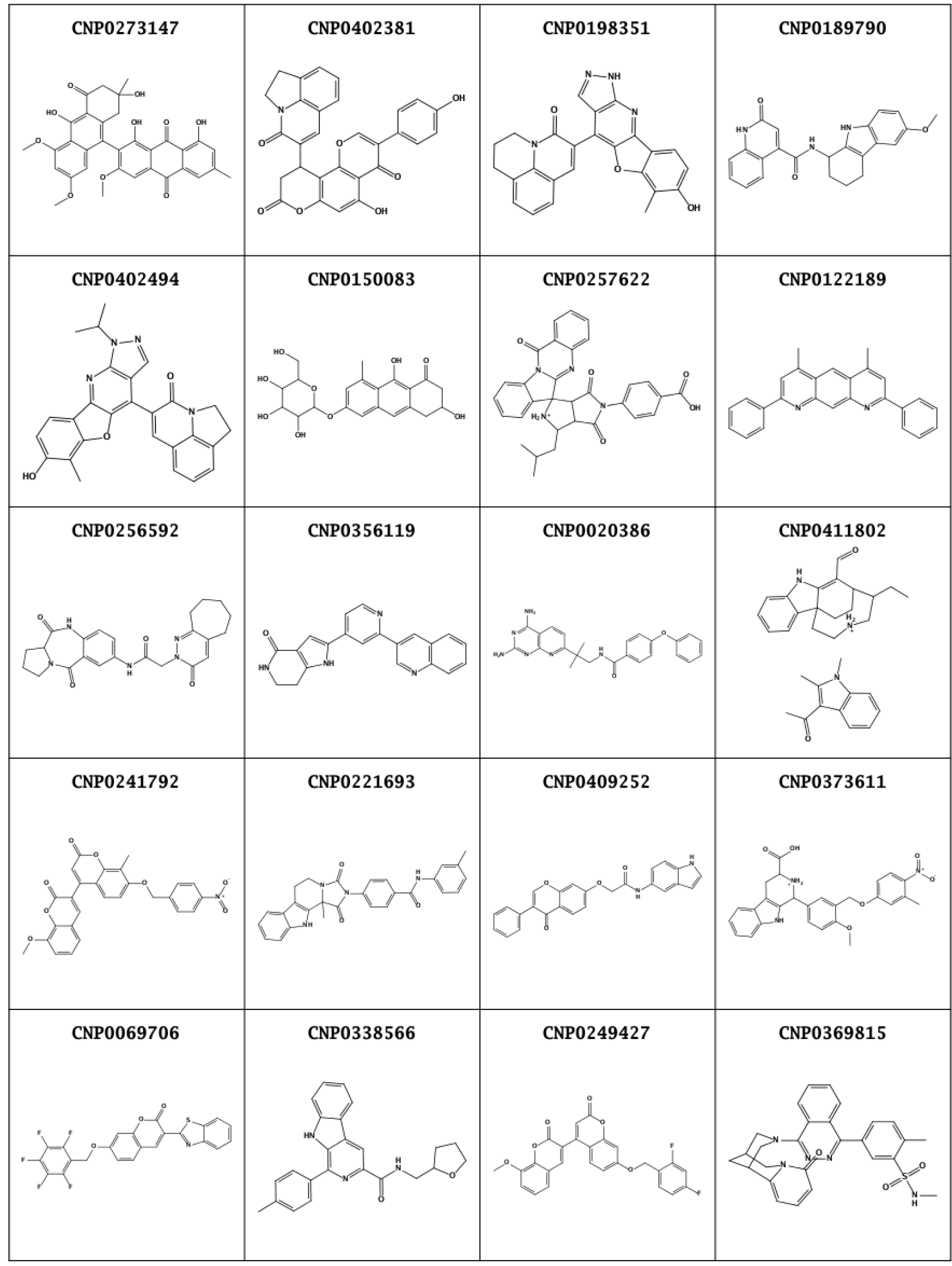




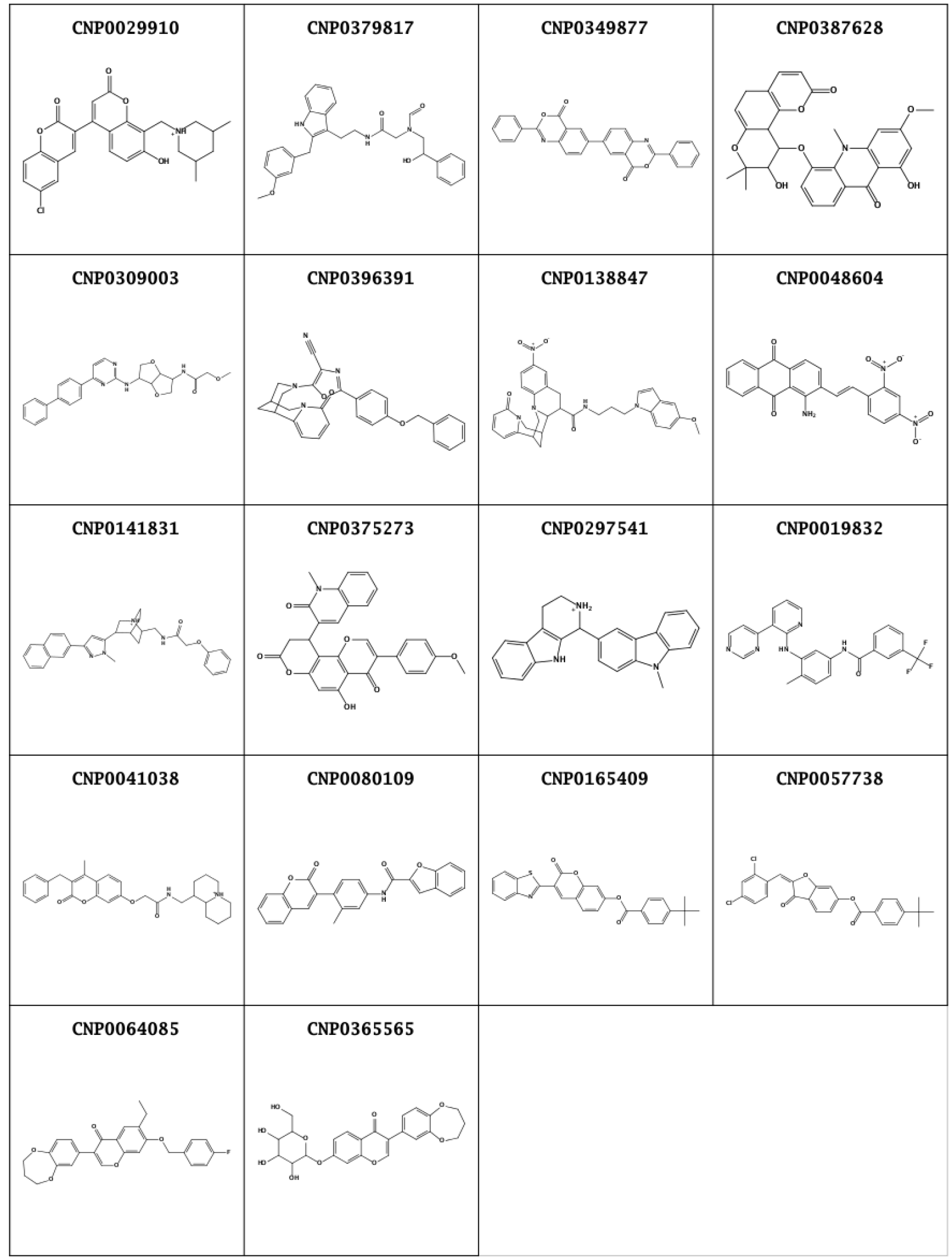




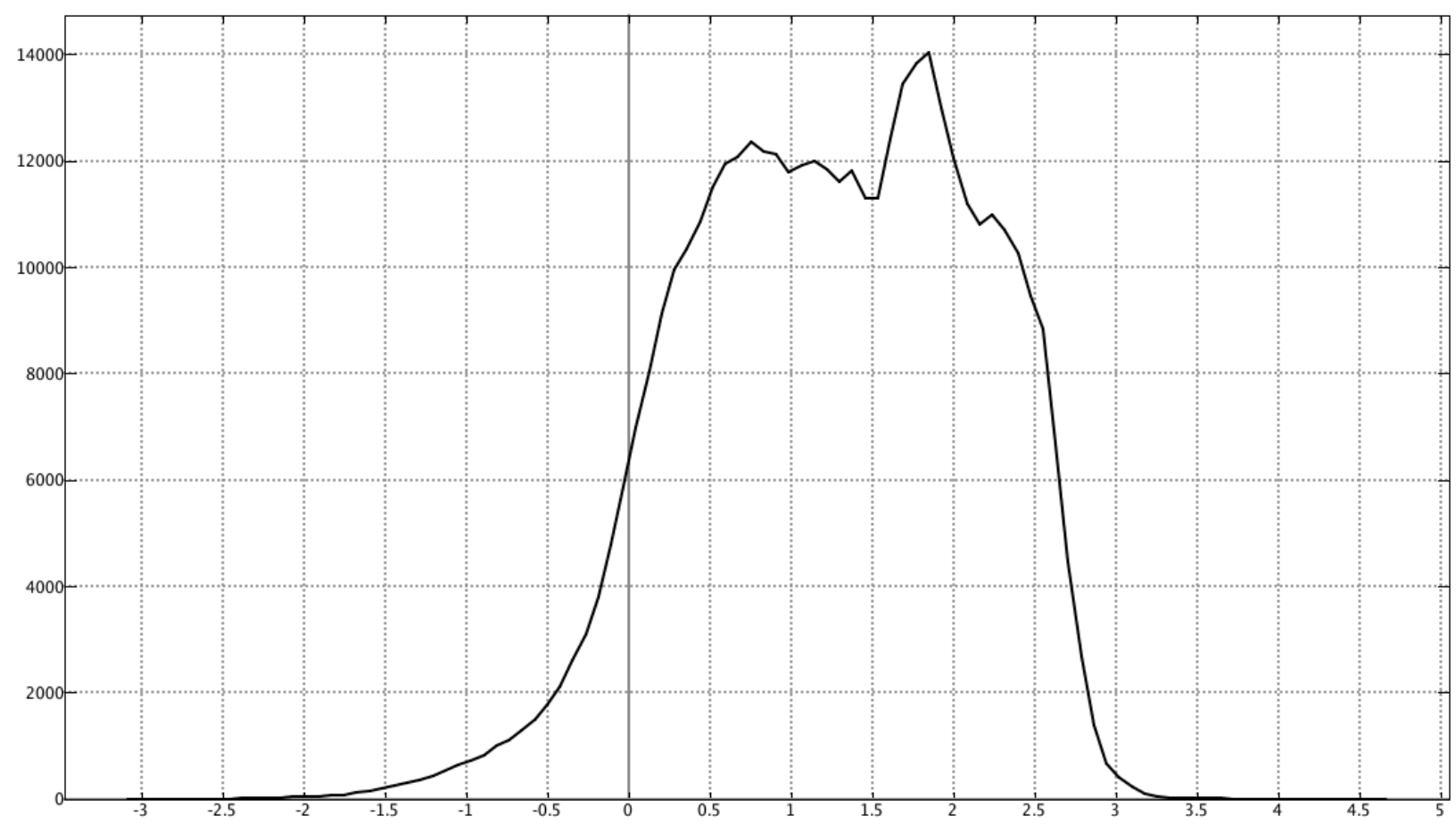

Figure SI-1: Distribution of NP scores in the top scoring natural products in the Coconut4 database

\section{PLpro hits matching all pharmacophore features}

\begin{tabular}{|c|c|c|c|c|c|}
\hline Coconut_ID & Docking_Score & molecular_formula & textTaxa & NPL_score & found_in_databases \\
\hline CNP0332080 & -8.5 & $\mathrm{C} 24 \mathrm{H} 26 \mathrm{O} 9$ & [notax] & 1.83 & [supernatural2 unpd] \\
\hline CNP0403695 & -8.5 & $\mathrm{C} 29 \mathrm{H} 24 \mathrm{~N} 2 \mathrm{O} 5$ & [notax] & 0.39 & [ibs2019mar_nc] \\
\hline CNP0110823 & -8.5 & C31H31N5O5 & [notax] & 0.44 & [zincnp] \\
\hline CNP0376441 & -8.4 & [C26H26N3O5S]- & [notax] & -0.21 & [chembl_np] \\
\hline CNP0077894 & -8.4 & $\mathrm{C} 25 \mathrm{H} 18 \mathrm{~N} 2 \mathrm{~S}$ & [notax] & -0.69 & [supernatural2] \\
\hline CNP0382733 & -8.3 & $\mathrm{C} 22 \mathrm{H} 14 \mathrm{~N} 4 \mathrm{O} 3$ & [notax] & -0.10 & [ibs2019mar_nc] \\
\hline CNP0183607 & -8.3 & $\mathrm{C} 29 \mathrm{H} 34 \mathrm{~N} 4 \mathrm{O} 2$ & [notax] & 1.09 & [zincnp] \\
\hline CNP0287331 & -8.3 & C31H31N5O4S & [notax] & 0.34 & [zincnp] \\
\hline CNP0356119 & -8.2 & $\mathrm{C} 21 \mathrm{H} 16 \mathrm{~N} 4 \mathrm{O}$ & [notax] & -0.29 & [drugbanknp] \\
\hline CNP0349877 & -8.1 & $\mathrm{C} 28 \mathrm{H} 16 \mathrm{~N} 2 \mathrm{O} 4$ & [notax] & -0.75 & $\begin{array}{l}\text { [ibs2019mar_nc } \\
\text { supernatural2] }\end{array}$ \\
\hline CNP0309003 & -8.1 & $\mathrm{C} 25 \mathrm{H} 26 \mathrm{~N} 4 \mathrm{O} 4$ & [notax] & 0.65 & $\begin{array}{l}\text { [supernatural2 } \\
\text { zincnp] }\end{array}$ \\
\hline CNP0396391 & -8.1 & $\mathrm{C} 28 \mathrm{H} 24 \mathrm{~N} 4 \mathrm{O} 3$ & [notax] & -0.02 & $\begin{array}{l}\text { [ibs2019mar_nc } \\
\text { supernatural2] }\end{array}$ \\
\hline CNP0141831 & -8.1 & [C3OH33N4O2]+ & [notax] & 0.29 & [supernatural2] \\
\hline CNP0297541 & -8.1 & $\mathrm{C} 24 \mathrm{H} 21 \mathrm{~N} 3$ & [notax] & 0.16 & [ibs2019mar_nc] \\
\hline
\end{tabular}

\section{PLpro hits that matching at least 3 of $\mathbf{5}$ pharmacophore features}

\begin{tabular}{|l|l|l|l|l|l|}
\hline Coconut_ID & Docking_Score & molecular_formula & textTaxa & NPL_score & found_in_databases \\
\hline CNP0332080 & -8.5 & C24H26O9 & [notax] & 1.83 & [supernatural2 unpd] \\
\hline CNP0403695 & -8.5 & $\mathrm{C} 29 \mathrm{H} 24 \mathrm{~N} 2 \mathrm{O} 5$ & {$[$ notax] } & 0.39 & [ibs2019mar_nc] \\
\hline CNP0408592 & -8.5 & $\mathrm{C} 23 \mathrm{H} 16 \mathrm{~N} 4 \mathrm{O} 3$ & {$[$ notax] } & -0.03 & [ibs2019mar_nc] \\
\hline CNP0110823 & -8.5 & $\mathrm{C} 31 \mathrm{H} 31 \mathrm{~N} 5 \mathrm{O} 5$ & {$[$ notax] } & 0.44 & [zincnp] \\
\hline CNP0228546 & -8.5 & $\mathrm{C} 31 \mathrm{H} 24 \mathrm{O} 9$ & [notax] & 1.58 & [supernatural2 unpd] \\
\hline
\end{tabular}




\begin{tabular}{|c|c|c|c|c|c|}
\hline CNP0368276 & -8.5 & $\mathrm{C} 28 \mathrm{H} 20 \mathrm{~N} 2 \mathrm{O} 5$ & [notax] & -0.36 & $\begin{array}{l}\text { [ibs2019mar_nc } \\
\text { supernatural2] }\end{array}$ \\
\hline CNP0093767 & -8.4 & $\mathrm{C} 29 \mathrm{H} 25 \mathrm{NO} 7$ & [plants] & 0.06 & [tcmdb_taiwan] \\
\hline CNP0393385 & -8.4 & $\mathrm{C} 24 \mathrm{H} 21 \mathrm{~N} 3 \mathrm{O} 4$ & [notax] & 0.46 & [ibs2019mar_nc] \\
\hline CNP0386161 & -8.4 & $\mathrm{C} 30 \mathrm{H} 25 \mathrm{CIN} 2 \mathrm{O} 7$ & [notax] & 0.57 & [ibs2019mar_nc] \\
\hline CNP0376441 & -8.4 & [C26H26N3O5S]- & [notax] & -0.21 & [chembl_np] \\
\hline CNP0077894 & -8.4 & $\mathrm{C} 25 \mathrm{H} 18 \mathrm{~N} 2 \mathrm{~S}$ & [notax] & -0.69 & [supernatural2] \\
\hline CNP0420259 & -8.3 & $\mathrm{C} 33 \mathrm{H} 34 \mathrm{O} 9$ & [plants] & 0.83 & $\begin{array}{l}\text { [tcmdb_taiwan } \\
\text { supernatural2 } \\
\text { zincnp] }\end{array}$ \\
\hline CNP0322100 & -8.3 & $\mathrm{C} 21 \mathrm{H} 20 \mathrm{O} 10$ & [notax] & 1.24 & [supernatural2 unpd] \\
\hline CNP0382733 & -8.3 & $\mathrm{C} 22 \mathrm{H} 14 \mathrm{~N} 4 \mathrm{O} 3$ & [notax] & -0.10 & [ibs2019mar_nc] \\
\hline CNP0183607 & -8.3 & $\mathrm{C} 29 \mathrm{H} 34 \mathrm{~N} 4 \mathrm{O} 2$ & [notax] & 1.09 & [zincnp] \\
\hline CNP0287331 & -8.3 & C31H31N5O4S & [notax] & 0.34 & [zincnp] \\
\hline CNP0273147 & -8.3 & $\mathrm{C} 33 \mathrm{H} 28 \mathrm{O} 10$ & [notax] & 1.35 & [supernatural2 unpd] \\
\hline CNP0402381 & -8.3 & $\mathrm{C} 29 \mathrm{H} 19 \mathrm{NO} 7$ & [notax] & 1.03 & [ibs2019mar_nc] \\
\hline CNP0198351 & -8.3 & $\mathrm{C} 25 \mathrm{H} 18 \mathrm{~N} 4 \mathrm{O} 3$ & [notax] & 0.28 & [ibs2019mar_nc] \\
\hline CNP0189790 & -8.3 & $\mathrm{C} 23 \mathrm{H} 21 \mathrm{~N} 3 \mathrm{O} 3$ & [notax] & 0.32 & [ibs2019mar_nc] \\
\hline CNP0402494 & -8.3 & $\mathrm{C} 27 \mathrm{H} 22 \mathrm{~N} 4 \mathrm{O} 3$ & [notax] & 0.34 & [ibs2019mar_nc] \\
\hline CNP0150083 & -8.3 & $\mathrm{C} 21 \mathrm{H} 24 \mathrm{O} 9$ & [notax] & 2.04 & [supernatural2 unpd] \\
\hline CNP0257622 & -8.3 & $\mathrm{C} 31 \mathrm{H} 26 \mathrm{~N} 4 \mathrm{O} 5$ & [notax] & 0.43 & [ibs2019mar_nc] \\
\hline CNP0122189 & -8.3 & $\mathrm{C} 26 \mathrm{H} 20 \mathrm{~N} 2$ & [notax] & -0.45 & [supernatural2] \\
\hline CNP0301743 & -8.2 & $\mathrm{C} 2 \mathrm{OH} 13 \mathrm{~N} 3 \mathrm{O} 2$ & $\begin{array}{l}\text { [Fungus fungi } \\
\text { epidendrum } \\
\text { Lycogala] }\end{array}$ & 0.20 & $\begin{array}{l}\text { [npatlas } \\
\text { np_atlas_2019_12 } \\
\text { unpd npass] }\end{array}$ \\
\hline CNP0292046 & -8.2 & $\mathrm{C} 25 \mathrm{H} 28 \mathrm{O} 4$ & [plants] & 1.49 & $\begin{array}{lr}\text { conmednp } & \text { cmaup } \\
\text { supernatural2 } & \text { tcmid } \\
\text { unpd p-anapl] } & \end{array}$ \\
\hline CNP0256592 & -8.2 & $\mathrm{C} 23 \mathrm{H} 25 \mathrm{~N} 5 \mathrm{O} 4$ & [notax] & 0.35 & [ibs2019mar_nc] \\
\hline CNP0356119 & -8.2 & $\mathrm{C} 21 \mathrm{H} 16 \mathrm{~N} 4 \mathrm{O}$ & [notax] & -0.29 & [drugbanknp] \\
\hline CNP0020386 & -8.2 & $\mathrm{C} 24 \mathrm{H} 24 \mathrm{~N} 6 \mathrm{O} 2$ & [notax] & -0.13 & [drugbanknp] \\
\hline CNP0411802 & -8.2 & [C31H32N3O2]+ & [notax] & 0.72 & [ibs2019mar_nc] \\
\hline CNP0241792 & -8.2 & $\mathrm{C} 27 \mathrm{H} 19 \mathrm{NO} 8$ & [notax] & 0.09 & $\begin{array}{l}\text { [ibs2019mar_nc } \\
\text { supernatural2] }\end{array}$ \\
\hline CNP0221693 & -8.2 & $\mathrm{C} 28 \mathrm{H} 24 \mathrm{~N} 4 \mathrm{O} 3$ & [notax] & -0.04 & [ibs2019mar_nc] \\
\hline CNP0409252 & -8.2 & $\mathrm{C} 25 \mathrm{H} 18 \mathrm{~N} 2 \mathrm{O} 4$ & [notax] & -0.06 & [ibs2019mar_nc] \\
\hline CNP0373611 & -8.2 & $\mathrm{C} 27 \mathrm{H} 25 \mathrm{~N} 3 \mathrm{O} 6$ & [notax] & 0.15 & [ibs2019mar_nc] \\
\hline CNP0069706 & -8.2 & C23H10F5NO3S & [notax] & -0.81 & [supernatural2] \\
\hline CNP0265390 & -8.1 & $\mathrm{C} 28 \mathrm{H} 26 \mathrm{O} 5$ & $\begin{array}{l}\text { [Fungus } \\
\text { Aspergillus } \\
\text { versicolor LCJ-5 } \\
\text { fungi] }\end{array}$ & 0.45 & $\begin{array}{l}\text { [npatlas } \\
\text { np_atlas_2019_12 } \\
\text { unpd] }\end{array}$ \\
\hline CNP0245001 & -8.1 & $\mathrm{C} 25 \mathrm{H} 18 \mathrm{~N} 4 \mathrm{O} 2$ & $\begin{array}{l}\text { [Fungus } \\
\text { Aspergillus } \\
\text { alliaceus ATCC } \\
\text { 20655] }\end{array}$ & -0.08 & $\begin{array}{l}\text { [np_atlas_2019_12 } \\
\text { unpd] }\end{array}$ \\
\hline CNP0338566 & -8.1 & $\mathrm{C} 24 \mathrm{H} 23 \mathrm{~N} 3 \mathrm{O} 2$ & [notax] & 0.30 & $\begin{array}{l}\text { [npedia } \\
\text { ibs2019mar_nc] }\end{array}$ \\
\hline CNP0249427 & -8.1 & $\mathrm{C} 26 \mathrm{H} 16 \mathrm{~F} 2 \mathrm{O} 6$ & [notax] & 0.07 & $\begin{array}{l}\text { [ibs2019mar_nc } \\
\text { supernatural2] }\end{array}$ \\
\hline CNP0369815 & -8.1 & C27H27N5O3S & [notax] & -0.30 & [ibs2019mar_nc] \\
\hline CNP0029910 & -8.1 & {$[\mathrm{C} 26 \mathrm{H} 25 \mathrm{CINO} 5]+$} & [notax] & 0.67 & [supernatural2] \\
\hline CNP0379817 & -8.1 & $\mathrm{C} 29 \mathrm{H} 27 \mathrm{~N} 3 \mathrm{O} 4$ & [notax] & 0.40 & [ibs2019mar_nc] \\
\hline CNP0349877 & -8.1 & $\mathrm{C} 28 \mathrm{H} 16 \mathrm{~N} 2 \mathrm{O} 4$ & [notax] & -0.75 & $\begin{array}{l}\text { [ibs2019mar_nc } \\
\text { supernatural2] }\end{array}$ \\
\hline CNP0387628 & -8.1 & $\mathrm{C} 29 \mathrm{H} 25 \mathrm{NO} 8$ & [notax] & 1.12 & $\begin{array}{l}\text { [fooddb } \\
\text { supernatural2 unpd] }\end{array}$ \\
\hline CNP0309003 & -8.1 & $\mathrm{C} 25 \mathrm{H} 26 \mathrm{~N} 4 \mathrm{O} 4$ & [notax] & 0.65 & $\begin{array}{l}\text { [supernatural2 } \\
\text { zincnp] }\end{array}$ \\
\hline
\end{tabular}




\begin{tabular}{|c|c|c|c|c|c|}
\hline CNP0396391 & -8.1 & $\mathrm{C} 28 \mathrm{H} 24 \mathrm{~N} 4 \mathrm{O} 3$ & [notax] & -0.02 & $\begin{array}{l}\text { [ibs2019mar_nc } \\
\text { supernatural2] }\end{array}$ \\
\hline CNP0138847 & -8.1 & C32H33N5O5 & [notax] & 0.48 & [ibs2019mar_nc] \\
\hline CNP0048604 & -8.1 & $\mathrm{C} 22 \mathrm{H} 13 \mathrm{~N} 3 \mathrm{O} 6$ & [notax] & -0.81 & [supernatural2] \\
\hline CNP0141831 & -8.1 & {$[\mathrm{C} 30 \mathrm{H} 33 \mathrm{~N} 4 \mathrm{O} 2]+$} & [notax] & 0.29 & [supernatural2] \\
\hline CNP0375273 & -8.1 & $\mathrm{C} 29 \mathrm{H} 21 \mathrm{NO} 7$ & [notax] & 0.79 & $\begin{array}{l}\text { [ibs2019mar_nc } \\
\text { supernatural2] }\end{array}$ \\
\hline CNP0297541 & -8.1 & $\mathrm{C} 24 \mathrm{H} 21 \mathrm{~N} 3$ & [notax] & 0.16 & [ibs2019mar_nc] \\
\hline CNP0019832 & -8.1 & C24H18F3N5O & [notax] & -0.72 & [drugbanknp] \\
\hline CNP0041038 & -8.1 & {$[\mathrm{C} 29 \mathrm{H} 35 \mathrm{~N} 2 \mathrm{O} 4]+$} & [notax] & 0.80 & [supernatural2] \\
\hline CNP0080109 & -8.1 & $\mathrm{C} 25 \mathrm{H} 17 \mathrm{NO} 4$ & [notax] & -0.25 & [zincnp] \\
\hline CNP0165409 & -8.1 & $\mathrm{C} 27 \mathrm{H} 21 \mathrm{NO} 4 \mathrm{~S}$ & [notax] & -0.16 & [supernatural2] \\
\hline CNP0057738 & -8.1 & $\mathrm{C} 26 \mathrm{H} 20 \mathrm{Cl} 2 \mathrm{O} 4$ & [notax] & -0.04 & [supernatural2] \\
\hline CNP0064085 & -8.1 & $\mathrm{C} 27 \mathrm{H} 23 \mathrm{FO} 5$ & [notax] & 0.45 & [supernatural2] \\
\hline CNP0365565 & -8.1 & $\mathrm{C} 24 \mathrm{H} 24 \mathrm{O} 10$ & [notax] & 0.93 & $\begin{array}{l}\text { [ibs2019mar_nc } \\
\text { supernatural2] }\end{array}$ \\
\hline
\end{tabular}

Spike protein hits matching at least 4 of 7 pharmacophore features (stereochemistry indicated for chiral compounds)

\begin{tabular}{|c|c|c|c|c|c|}
\hline Coconut_ID & Docking_Score & molecular_formula & textTaxa & NPL_score & found_in_databases \\
\hline CNP0113725 & -9.4 & $\mathrm{C} 18 \mathrm{H} 15 \mathrm{~N} 5 \mathrm{O}$ & [notax] & 0.36 & [zincnp] \\
\hline CNP0285404_s & -9.3 & $\mathrm{C} 31 \mathrm{H} 26 \mathrm{~N} 2 \mathrm{O} 6$ & [notax] & 0.52 & [ibs2019mar_nc] \\
\hline CNP0409713_s & -9.3 & $\mathrm{C} 27 \mathrm{H} 20 \mathrm{O} 7$ & [notax] & 0.80 & [ibs2019mar_nc] \\
\hline CNP0403008 & -9.2 & $\mathrm{C} 25 \mathrm{H} 26 \mathrm{~N} 2 \mathrm{O} 3$ & [notax] & 0.95 & [ibs2019mar_nc] \\
\hline CNP0132136 & -9.2 & $\mathrm{C} 24 \mathrm{H} 22 \mathrm{O} 6$ & [notax] & 1.40 & [unpd] \\
\hline CNP0323621 & -9.2 & $\mathrm{C} 26 \mathrm{H} 21 \mathrm{NO} 6$ & [notax] & 0.30 & [ibs2019mar_nc] \\
\hline CNP0212508 & -9.1 & $\mathrm{C} 24 \mathrm{H} 26 \mathrm{~N} 6 \mathrm{O} 2$ & [notax] & 0.30 & [zincnp] \\
\hline CNP0196493 & -9.1 & $\mathrm{C} 25 \mathrm{H} 18 \mathrm{O} 5$ & [notax] & 0.77 & [ibs2019mar_nc] \\
\hline CNP0129938 & -9.1 & $\mathrm{C} 27 \mathrm{H} 22 \mathrm{~N} 2 \mathrm{O} 2$ & [notax] & 0.01 & [npass] \\
\hline CNP0012180 & -9.1 & $\mathrm{C} 21 \mathrm{H} 22 \mathrm{~N} 8 \mathrm{O}$ & [notax] & 0.27 & [zincnp] \\
\hline CNP0239713_r & -9.0 & $\mathrm{C} 28 \mathrm{H} 25 \mathrm{NO} 6$ & [notax] & 0.63 & [ibs2019mar_nc] \\
\hline CNP0168743_s & -9.0 & $\mathrm{C} 25 \mathrm{H} 26 \mathrm{O} 5$ & [notax] & 1.56 & [supernatural2 unpd] \\
\hline CNP0334196 & -8.9 & $\mathrm{C} 30 \mathrm{H} 36 \mathrm{O} 4$ & [plants] & 1.56 & $\begin{array}{l}\text { [npact } \quad \text { zincnp } \\
\text { npcare] }\end{array}$ \\
\hline CNP0233013 & -8.9 & [C22H17O6]+ & [plants] & 0.98 & [tcmdb_taiwan] \\
\hline CNP0125961 & -8.9 & $\mathrm{C} 25 \mathrm{H} 16 \mathrm{O} 5$ & [notax] & 0.37 & [ibs2019mar_nc] \\
\hline CNP0224601 & -8.9 & $\mathrm{C} 2 \mathrm{OH} 18 \mathrm{O} 4$ & [notax] & 1.36 & [unpd] \\
\hline CNP0198440_s & -8.9 & $\mathrm{C} 34 \mathrm{H} 33 \mathrm{~N} 3 \mathrm{O} 7$ & [notax] & 0.56 & [ibs2019mar_nc] \\
\hline CNP0375993 & -8.8 & [C18H11N2O4]+ & $\begin{array}{l}\text { [murayamaensis } \\
\text { Bacterium } \\
\text { bacteria } \\
\text { Streptomyces] }\end{array}$ & 1.05 & $\begin{array}{l}\text { [npatlas } \\
\text { np_atlas_2019_12] }\end{array}$ \\
\hline CNP0230664 & -8.8 & $\mathrm{C} 26 \mathrm{H} 21 \mathrm{ClO} 5$ & [notax] & 0.24 & [supernatural2] \\
\hline
\end{tabular}

\section{Mpro hits matching all pharmacophore features}

\begin{tabular}{|l|l|l|l|l|l|}
\hline Coconut_ID & Docking_Score & molecular_formula & textTaxa & NPL_score & found_in_databases \\
\hline CNP0131030 & -9.5 & C31H25CIN4O5 & [notax] & 0.49 & [ibs2019mar_nc] \\
\hline
\end{tabular}




\begin{tabular}{|c|c|c|c|c|c|}
\hline CNP0414324 & -9.4 & $\mathrm{C} 29 \mathrm{H} 24 \mathrm{CIN} 3 \mathrm{O} 7$ & [notax] & 0.68 & [ibs2019mar_nc] \\
\hline CNP0120445 & -9.2 & $\mathrm{C} 26 \mathrm{H} 23 \mathrm{~F} 2 \mathrm{~N} 3 \mathrm{O} 3$ & [notax] & 0.02 & [zincnp] \\
\hline CNP0061637 & -9.1 & $\mathrm{C} 26 \mathrm{H} 26 \mathrm{BrNO} 4$ & [notax] & 0.92 & [supernatural2] \\
\hline CNP0390225 & -9.1 & $\mathrm{C} 27 \mathrm{H} 28 \mathrm{~N} 4 \mathrm{O} 3$ & [notax] & 0.77 & [ibs2019mar_nc] \\
\hline CNP0352209 & -9.0 & $\mathrm{C} 28 \mathrm{H} 25 \mathrm{~N} 3 \mathrm{O} 7$ & $\begin{array}{l}\text { [Bacterium } \\
\text { bacteria } \\
\text { Actinomadura } \\
\text { melliaura ATCC } \\
\text { 39691] }\end{array}$ & -0.06 & $\begin{array}{l}\text { [npatlas } \\
\text { np_atlas_2019_12 } \\
\text { npass] }\end{array}$ \\
\hline CNP0390606 & -9.0 & $\mathrm{C} 30 \mathrm{H} 23 \mathrm{CIN} 4 \mathrm{O} 5$ & [notax] & 0.37 & [ibs2019mar_nc] \\
\hline CNP0362995 & -9.0 & C33H36N4O6 & [notax] & 0.50 & $\begin{array}{l}\text { [ibs2019mar_nc } \\
\text { supernatural2] }\end{array}$ \\
\hline CNP0390969 & -9.0 & $\mathrm{C} 32 \mathrm{H} 30 \mathrm{~N} 4 \mathrm{O} 5$ & [notax] & 0.45 & [ibs2019mar_nc] \\
\hline CNP0374052 & -9.0 & $\mathrm{C} 21 \mathrm{H} 17 \mathrm{CIN} 4 \mathrm{O} 6$ & [notax] & 1.03 & [ibs2019mar_nc] \\
\hline CNP0042143 & -8.9 & [C25H25N2O5]+ & [notax] & 0.83 & [supernatural2] \\
\hline CNP0370364 & -8.9 & [C26H29N4O6]+ & [notax] & 0.46 & $\begin{array}{l}\text { [ibs2019mar_nc } \\
\text { supernatural2] }\end{array}$ \\
\hline CNP0390684 & -8.9 & C31H29FN4O3 & [notax] & 0.40 & [ibs2019mar_nc] \\
\hline CNP0331417 & -8.9 & $\mathrm{C} 23 \mathrm{H} 18 \mathrm{O} 8$ & [notax] & 1.29 & [supernatural2 unpd] \\
\hline CNP0373422 & -8.9 & $\mathrm{C} 32 \mathrm{H} 29 \mathrm{CIN} 4 \mathrm{O} 5$ & [notax] & 0.55 & [ibs2019mar_nc] \\
\hline
\end{tabular}

\section{Mpro hits matchomg at least $\mathbf{3}$ of $\mathbf{4}$ pharmacophore features}

\begin{tabular}{|c|c|c|c|c|c|}
\hline Coconut_ID & Docking_Score & molecular_formula & textTaxa & NPL_score & found_in_databases \\
\hline CNP0131030 & -9.5 & C31H25CIN4O5 & [notax] & 0.49 & [ibs2019mar_nc] \\
\hline CNP0228228 & -9.5 & $\mathrm{C} 29 \mathrm{H} 30 \mathrm{~N} 4 \mathrm{O} 4$ & [notax] & 0.78 & [ibs2019mar_nc] \\
\hline CNP0369441 & -9.4 & [C34H41FNO5]+ & [notax] & 1.46 & [supernatural2] \\
\hline CNP0414324 & -9.4 & $\mathrm{C} 29 \mathrm{H} 24 \mathrm{CIN} 3 \mathrm{O} 7$ & [notax] & 0.68 & [ibs2019mar_nc] \\
\hline CNP0037401 & -9.4 & [C26H19O5]- & [notax] & 0.90 & [supernatural2] \\
\hline CNP0380989 & -9.3 & $\mathrm{C} 27 \mathrm{H} 32 \mathrm{~N} 4 \mathrm{O} 4$ & [notax] & 0.90 & [ibs2019mar_nc] \\
\hline CNP0413646 & -9.3 & $\mathrm{C} 28 \mathrm{H} 28 \mathrm{~N} 4 \mathrm{O} 4$ & [notax] & 0.74 & [ibs2019mar_nc] \\
\hline CNP0120445 & -9.2 & $\mathrm{C} 26 \mathrm{H} 23 \mathrm{~F} 2 \mathrm{~N} 3 \mathrm{O} 3$ & [notax] & 0.03 & [zincnp] \\
\hline CNP0252890 & -9.2 & $\mathrm{C} 28 \mathrm{H} 33 \mathrm{ClO} 6$ & [notax] & 2.12 & [supernatural2 unpd] \\
\hline CNP0328498 & -9.1 & $\mathrm{C} 26 \mathrm{H} 22 \mathrm{~N} 2 \mathrm{O} 4$ & [plants] & 0.70 & $\begin{array}{l}\text { [cmaup } \\
\text { supernatural2 unpd } \\
\text { npass] }\end{array}$ \\
\hline CNP0061637 & -9.1 & $\mathrm{C} 26 \mathrm{H} 26 \mathrm{BrNO} 4$ & [notax] & 0.92 & [supernatural2] \\
\hline CNP0293624 & -9.1 & $\mathrm{C} 24 \mathrm{H} 33 \mathrm{~N} 7 \mathrm{O} 5$ & [notax] & 0.90 & [supernatural2] \\
\hline
\end{tabular}




\begin{tabular}{|c|c|c|c|c|c|}
\hline CNP0390225 & -9.1 & $\mathrm{C} 27 \mathrm{H} 28 \mathrm{~N} 4 \mathrm{O} 3$ & [notax] & 0.77 & [ibs2019mar_nc] \\
\hline CNP0055030 & -9.1 & [C24H12NO5]- & [notax] & 0.34 & [supernatural2] \\
\hline CNP0352209 & -9.0 & $\mathrm{C} 28 \mathrm{H} 25 \mathrm{~N} 3 \mathrm{O} 7$ & $\begin{array}{l}\text { [Bacterium } \\
\text { bacteria } \\
\text { Actinomadura } \\
\text { melliaura } \\
\text { ATCC 39691] }\end{array}$ & -0.06 & $\begin{array}{l}\text { [npatlas } \\
\text { np_atlas_2019_12 } \\
\text { npass] }\end{array}$ \\
\hline CNP0390606 & -9.0 & $\mathrm{C} 30 \mathrm{H} 23 \mathrm{CIN} 4 \mathrm{O} 5$ & [notax] & 0.37 & [ibs2019mar_nc] \\
\hline CNP0201098 & -9.0 & [C26H20N3O4]- & [notax] & -0.19 & [supernatural2] \\
\hline CNP0245259 & -9.0 & C24H21FN4O2 & [notax] & 0.13 & [zincnp] \\
\hline CNP0362995 & -9.0 & C33H36N4O6 & [notax] & 0.50 & $\begin{array}{l}\text { [ibs2019mar_nc } \\
\text { supernatural2] }\end{array}$ \\
\hline CNP0393487 & -9.0 & $\mathrm{C} 26 \mathrm{H} 18 \mathrm{O} 10$ & [notax] & 1.35 & [ibs2019mar_nc] \\
\hline CNP0390629 & -9.0 & $\mathrm{C} 32 \mathrm{H} 30 \mathrm{~N} 4 \mathrm{O} 6$ & [notax] & 0.56 & [ibs2019mar_nc] \\
\hline CNP0390969 & -9.0 & $\mathrm{C} 32 \mathrm{H} 30 \mathrm{~N} 4 \mathrm{O} 5$ & [notax] & 0.45 & [ibs2019mar_nc] \\
\hline CNP0401185 & -9.0 & $\mathrm{C} 25 \mathrm{H} 24 \mathrm{~N} 2 \mathrm{O} 5$ & [notax] & 0.94 & [ibs2019mar_nc] \\
\hline CNP0273258 & -9.0 & $\mathrm{C} 28 \mathrm{H} 20 \mathrm{Cl} 2 \mathrm{O} 4$ & [notax] & 0.35 & [supernatural2 unpd] \\
\hline CNP0355623 & -9.0 & $\mathrm{C} 32 \mathrm{H} 32 \mathrm{~N} 4 \mathrm{O} 6$ & [notax] & 0.75 & [ibs2019mar_nc] \\
\hline CNP0374052 & -9.0 & $\mathrm{C} 21 \mathrm{H} 17 \mathrm{CIN} 4 \mathrm{O} 6$ & [notax] & 1.02 & [ibs2019mar_nc] \\
\hline CNP0236086 & -8.9 & $\mathrm{C} 25 \mathrm{H} 26 \mathrm{CIFN} 4 \mathrm{O} 3$ & [notax] & 0.41 & [zincnp] \\
\hline CNP0042143 & -8.9 & [C25H25N2O5]+ & [notax] & 0.83 & [supernatural2] \\
\hline CNP0403172 & -8.9 & $\mathrm{C} 29 \mathrm{H} 23 \mathrm{NO} 7$ & [notax] & 0.77 & [ibs2019mar_nc] \\
\hline CNP0161959 & -8.9 & C31H25NO9 & [notax] & 0.68 & [ibs2019mar_nc] \\
\hline CNP0370364 & -8.9 & [C26H29N4O6]+ & [notax] & 0.46 & $\begin{array}{l}\text { [ibs2019mar_nc } \\
\text { supernatural2] }\end{array}$ \\
\hline CNP0390684 & -8.9 & C31H29FN4O3 & [notax] & 0.40 & [ibs2019mar_nc] \\
\hline CNP0363620 & -8.9 & $\mathrm{C} 29 \mathrm{H} 44 \mathrm{O} 10$ & [notax] & 2.89 & [supernatural2 unpd] \\
\hline CNP0331417 & -8.9 & $\mathrm{C} 23 \mathrm{H} 18 \mathrm{O} 8$ & [notax] & 1.29 & [supernatural2 unpd] \\
\hline CNP0373422 & -8.9 & $\mathrm{C} 32 \mathrm{H} 29 \mathrm{CIN} 4 \mathrm{O} 5$ & [notax] & 0.54 & [ibs2019mar_nc] \\
\hline CNP0013026 & -8.9 & $\mathrm{C} 25 \mathrm{H} 24 \mathrm{~N} 4 \mathrm{O} 2$ & [notax] & 0.26 & [zincnp] \\
\hline CNP0381876 & -8.9 & C29H33NO5 & [notax] & 1.03 & $\begin{array}{l}\text { [ibs2019mar_nc } \\
\text { supernatural2] }\end{array}$ \\
\hline CNP0353621 & -8.8 & C19H17N7O3 & [notax] & -0.49 & [ibs2019mar_nc] \\
\hline
\end{tabular}

